\title{
A paradigm of extreme rainfall pluvial floods in complex urban areas: the flood event of 15 July 2020 in Palermo (Italy)
}

\author{
Antonio Francipane, Dario Pumo, Marco Sinagra, Goffredo La Loggia, and Leonardo Valerio Noto \\ Department of Engineering, University of Palermo, Palermo 90128, Italy
}

Correspondence: Antonio Francipane (antonio.francipane@unipa.it)

Received: 25 February 2021 - Discussion started: 4 March 2021

Revised: 15 July 2021 - Accepted: 29 July 2021 - Published: 26 August 2021

\begin{abstract}
In the last few years, some regions of the Mediterranean area have witnessed a progressive increase in extreme events, such as urban and flash floods, as a response to the increasingly frequent and severe extreme rainfall events, which are often exacerbated by the ever-growing urbanization. In such a context, the urban drainage systems may not be sufficient to convey the rainwater, thus increasing the risk deriving from the occurrence of such events.

This study focuses on a particularly intense urban flood that occurred in Palermo (Italy) on 15 July 2020; it represents a typical pluvial flood due to extreme rainfall on a complex urban area that many cities have experienced in recent years, especially in the Mediterranean region. A conceptual hydrological model and a 2D hydraulic model, particularly suitable for simulations in a very complex urban context, have been used to simulate the event. Results have been qualitatively validated by means of crowdsourced information and satellite images.

The experience of Palermo, which has highlighted the urgent need for a shift in the way stormwater in urban settlements is managed, can be assumed to be a paradigm for modeling pluvial floods in complex urban areas under extreme rainfall conditions. Although the approaches and the related policies cannot be identical for all cities, the modeling framework used here to assess the impacts of the event under study and some conclusive remarks could be easily transferred to other, different urban contexts.
\end{abstract}

\section{Introduction}

During the last few decades, floods and flash floods have reached unprecedented levels in several parts of the globe
(Andersson-Sköld and Nyberg, 2016; Gariano and Guzzetti, 2016; Hoeppe, 2016; IPCC, 2019; Jia et al., 2019; Messeri et al., 2015), including the Mediterranean region, where Sicily (Italy) has been one of the most affected areas in between 2008 and 2018 (Trigila and Iadanza, 2018).

Sicily is the largest island of the Mediterranean Sea and is characterized by a very complex morphology. The combination of its geographic position, morphology, and climate can lead to the generation of severe rainfall events, especially in between the end of summer and the fall. In that period, indeed, the warmer air masses that move over the hot water of the Mediterranean Sea increase their atmospheric moistureholding capacity (Drobinski et al., 2018; Pumo et al., 2019; Pumo and Noto, 2021) and, interacting with the steep orography on the coasts, can generate local convection processes that cause very heavy rainfall (Dayan et al., 2015; Sheffield and Wood, 2008; Tramblay and Somot, 2018). In the last few years, these rainfall events have become increasingly frequent and severe over the Mediterranean area (Arnone et al., 2013; Cipolla et al., 2020; IPCC, 2019), especially at the subhourly scale (Treppiedi et al., 2021), with a rainfall-runoff response often exacerbated by the ever-growing urbanization (Arnone et al., 2018; Easterling et al., 2000; Pumo et al., 2017).

Consequentially, in recent times, some intense rainfall events have caused urban floods and flash floods in many cities of the island, with consequent economic damages and, sometimes, loss of human life. For instance, on 1 October 2015, about $75 \mathrm{~mm}$ of rainfall, with an intensity peak of about $65 \mathrm{~mm} \mathrm{~h}^{-1}$, flooded the city of Catania, prompting the intervention of the Civil Protection Department to drain the streets with sump pumps. In November 2016, a $160 \mathrm{~mm}$ rain event with a duration of $3 \mathrm{~h}$ occurred in the city of Licata, 
causing damage and forcing the mayor of the city to adopt extreme measures for civil protection (e.g., people confined to their homes, closure of schools and all economic activities, etc.). On 8 August 2018, in only 20 min, precipitation of about $75 \mathrm{~mm} \mathrm{~h}^{-1}$ intensity endangered the city of Palermo, transforming the urban streets into rivers and flooding most of the old city and several other districts of the city. Between 1 and 3 November 2018, some heavy rainfall events in the eastern and southern parts of the region, between the cities of Trapani, Palermo, and Agrigento, caused 13 fatalities, and more than 230 people were displaced. In the town of Casteldaccia, $18 \mathrm{~km}$ away from the city of Palermo, a flash flood trapped and killed nine people in their homes. The rainfall peak over $3 \mathrm{~d}$ reached an intensity of about $190 \mathrm{~mm} \mathrm{~h}^{-1}$ in $5 \mathrm{~min}$, with a total rainfall depth of $180 \mathrm{~mm}$ in $3 \mathrm{~d}$, which is approximatively equal to about one-third of the mean annual precipitation of some of the affected areas. Figure S1 in the Supplement shows some of the impacts that these floods had on the territory that they affected.

All these flooding events occurred between the end of summer and the fall and can be related to a combined effect of convective precipitation, which saturates the urban drainage system very quickly, and the runoff due to the rain falling on elevated terrain (e.g., hillsides) that is scarcely able to infiltrate the water. Most of these floods can be classified as pluvial floods. Although this type of flood usually occurs gradually, with levels of water that rarely exceed $1 \mathrm{~m}$ (Palla et al., 2018; Stone et al., 2013; Sušnik et al., 2015) and does not cause an immediate threat to life, it may cause significant economic damage in some cases.

Modeling such a type of flood is never easy, especially when these affect very complex urban areas. Bulti and Abebe (2020) provided a review of the main flood modeling methods adopted for the study of pluvial floods, highlighting the benefits and drawbacks of each approach. Some approaches, such as rapid flood spreading (Lhomme et al., 2009; Wallingford, 2006), are easy to apply but return only the final state of inundation. Other approaches, such as the 1D approach, are recommended for studies that do not require high precision in describing the surface runoff routing, while still others, such as the 2D approach, seem to be more suitable for applications in urban areas where there is no stormwater drainage or the influence of stormwater drainage is considered insignificant for the flood phenomenon under study. Coupled models (i.e., 1D-2D) can provide accurate information but are computationally expensive both in terms of runtime and data requirements. In all cases, however, reliable modeling of the phenomenon always requires many different kinds of information and levels of accuracy, which are not always available or easy to obtain.

From this perspective, one of the main issues to deal with is the lack of observed data to be used as a reference for the calibration and validation of models (See, 2019). Indeed, different to the case of fluvial floods in gauged systems, where the monitoring of the rivers makes measures (i.e., water level, discharge, etc.) available in different points of the domain, in urban areas there are no gauged sites that provide water level observations. Nowadays, one of the possibilities for overcoming such a problem is represented by remote sensing data, which can provide the opportunity to quickly and precisely have an overview of the flooded areas (Di Baldassarre et al., 2009; Bates, 2012; Grimaldi et al., 2016). However, remote sensing data may not be always adequate to describe the evolution and the effects of a pluvial flood either because they are often not timeously available due to the satellite orbit revisit time (Annis and Nardi, 2019), which is especially true when floods have a rapid temporal evolution and limited flood area extent (Notti et al., 2018), or because the substantial areas of the urban ground surface may not be visible due to the shadow caused by buildings (Lu et al., 2010; Mason et al., 2014, 2021; Notti et al., 2018). In addition to remote sensing data, data gathered by citizens (i.e., crowdsourced data) are becoming increasingly important thanks to the widespread use of smartphones and social media (Hilbert, 2016). The growing availability of crowdsourced data, especially in urban areas, such as pictures and videos acquired with mobile devices (e.g., smartphones, tablets, digital cameras, etc.) and content sharing on social media platforms (e.g., YouTube, Facebook, Instagram, etc.), offers the possibility for scientists to gather precious information about the temporal and spatial evolution of flooding events to be used for the calibration of hydraulic models. Many studies have used crowdsourced data to investigate flood events in the last few years (Annis and Nardi, 2019; Mazzoleni et al., 2015, 2018; Smith et al., 2017; Yu et al., 2016).

Despite the highlighted difficulties, a correct pluvial flood model in a complex urban area is extremely important for correct residual risk management by means of opportune civil protection plans and the continuous updating of the flood emergency plans. Moreover, pluvial flood modeling can be useful for demonstrating how, in some cases, a drainage system may not be efficient and, thus, increase the hydraulic risk deriving from the occurrence of such events. Many of these systems, indeed, have been designed without considering the impacts of urbanization and climate change on natural systems and, for this reason, are no longer suitable for draining the rain coming from some extreme events that are likely to become more frequent and heavier. All of these aspects make it necessary for new paradigms in urban drainage design to develop new strategies for flood risk management based on the acceptance of a new concept in which flooding can be tolerated and viewed as a driver for societal development (La Loggia et al., 2020).

From this perspective, this study addresses questions regarding the way of dealing with the flood risk in urban settlements where the economic, social, and cultural conditions do not allow either for the building of new drainage systems or the upgrading of the existing ones. To do this, the study focuses on a particularly intense urban flood that occurred within the Uditore-Passo di Rigano district in Palermo on 
15 July 2020, which represents a typical extreme rainfall pluvial flood over a complex urban area that many cities, especially in the Mediterranean region, have experienced in recent years. On that occasion, the precipitation lasted about $2 \mathrm{~h}$, with a cumulative rainfall of $134 \mathrm{~mm}$ and an intensity peak of $168 \mathrm{~mm} \mathrm{~h}^{-1}$ in $5 \mathrm{~min}$, caused the flooding of the ring road of Palermo and its underpasses with damage to several cars and inconveniences to people. In that case, in addition to the precipitation, a significant impact on the flooding dynamic is surely attributable to the substantial alterations in the land use and land cover that have occurred over the last few decades, especially in the areas most affected by the event.

We capitalize on this event to create a modeling framework that can be assumed as a "paradigm" for those cases in which (i) complex hydrologic domains are linked to complex systems of natural channels integrated within an urban settlement, (ii) the domain is forced with extreme precipitation, and (iii) there is a lack of observed data but a plenty of crowdsourced data that can be used qualitatively to verify the reliability of results returned by the modeling chain.

The paper is organized as follows. Section 2 introduces the case study (i.e., the flooding event) and the analysis of the rainfall event that caused it. Section 3 describes the hydrological and hydraulic models used to model the forcing coming from the contributing basins around the study area and the propagation of the hydrographs within it, respectively, and the data used to validate the hydraulic model. The results and some insights about future management strategies are shown and discussed in Sect. 4. Section 5, finally, provides the main conclusions of the study.

\section{Case study: the Uditore-Passo di Rigano district in Palermo}

Palermo is the capital of Sicily (Italy), which is the largest island of the Mediterranean Sea (Fig. 1). The city lies on a valley of about $100 \mathrm{~km}^{2}$, called Conca d'Oro, in between the Mediterranean Sea and the mountains that reach a maximum elevation of about $1000 \mathrm{~m}$ a.s.1. (Fig. 1). The original hydrographic configuration of the city has been completely changed over the years. The two rivers that originally traversed the city, the Kemonia and the Papireto, have been forced underground, while there is only a river, the Oreto, that still runs on the surface. The city is characterized by some ephemeral streams, called valloni, that convey rainwater from the mountains and the hills around the city to the inner city, sometimes causing damage and inconveniencing the people.

The city has a Mediterranean climate, with hot and dry summers and cool and wet winters. The mean annual precipitation is about $800 \mathrm{~mm}$, with precipitation mostly concentrated in fall and winter, while the summer season (i.e., June, July, and August) is usually almost without rain. The mean

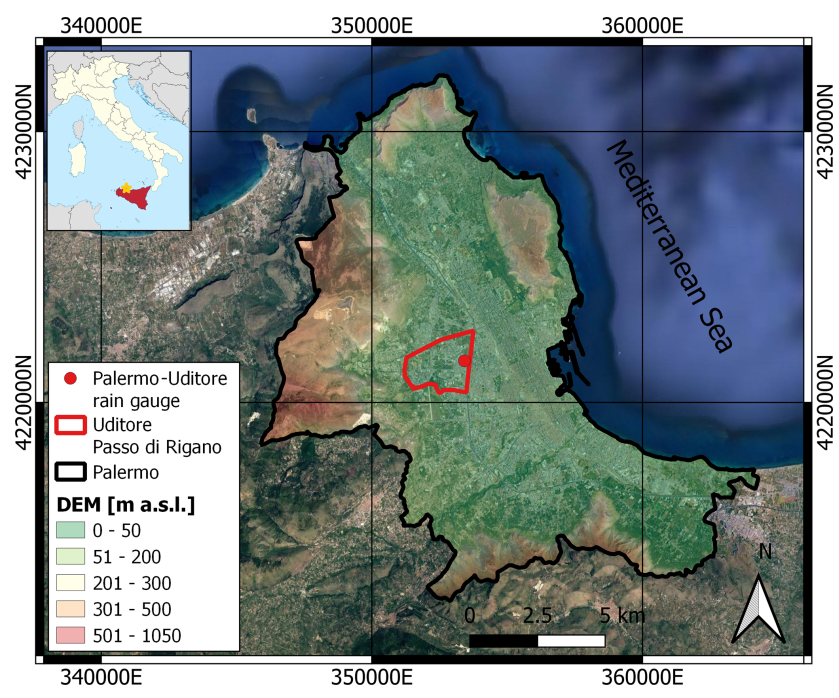

Figure 1. Aerial view of the city of Palermo (Sicily, Italy) overlaid on a digital elevation model (DEM). The red line and red point indicate the Uditore-Passo di Rigano district and the Uditore rain gauge station of the SIAS (Servizio Informativo Agrometeorologico Siciliano - Agrometeorological Information Service of Sicily) rain gauge network, respectively. The yellow star in the inset indicates the location of Palermo. Source: (C) Google Maps Satellite basemap available within the QuickMapServices plugin of Quantum GIS.

annual temperature is about $22^{\circ} \mathrm{C}$, with peaks higher than $35^{\circ} \mathrm{C}$ during the summer.

The study area (i.e., the Uditore-Passo di Rigano district; red line in Fig. 1) is located at the foot of Mount Cuccio (1050 $\mathrm{m}$ a.s.1.) and Mount Gibilforni (about $520 \mathrm{~m}$ a.s.l.) and is traversed by two of the most important streets of the city, i.e., via Leonardo Da Vinci and viale Michelangelo, the ring road of Palermo, also known as viale Regione Siciliana, and its underpasses below the two streets mentioned above (hereafter named Da Vinci underpass and Michelangelo underpass, respectively). The district includes a rather articulated water drainage system for the conveyance and regulation of rainwater (Fig. 2). It is made of the artificial channel, Passo di Rigano, with its left tributaries of Mortillaro, Celona, and Borsellino, which flow into a unique stream further downstream, and its right tributary of Luparello, which is an extension of the channel Passo di Rigano upstream of the confluence between the Celona and the Borsellino channels. This drainage system, which is almost completely underground and embedded within the urban structure, flows toward the industrial harbor of Palermo. In Fig. 2, within the colored boxes, the channel cross sections are shown (Oliveri, 1996).

As it is possible to observe in Fig. 3, there are four different main drainage areas that feed the abovementioned channels and mainly contribute to the total runoff formation within the study area. The outlets of the four contributing catchments (yellow circles in Fig. 3) match with the starting points of the covered parts of channels (i.e., culverts) of Mortillaro, 


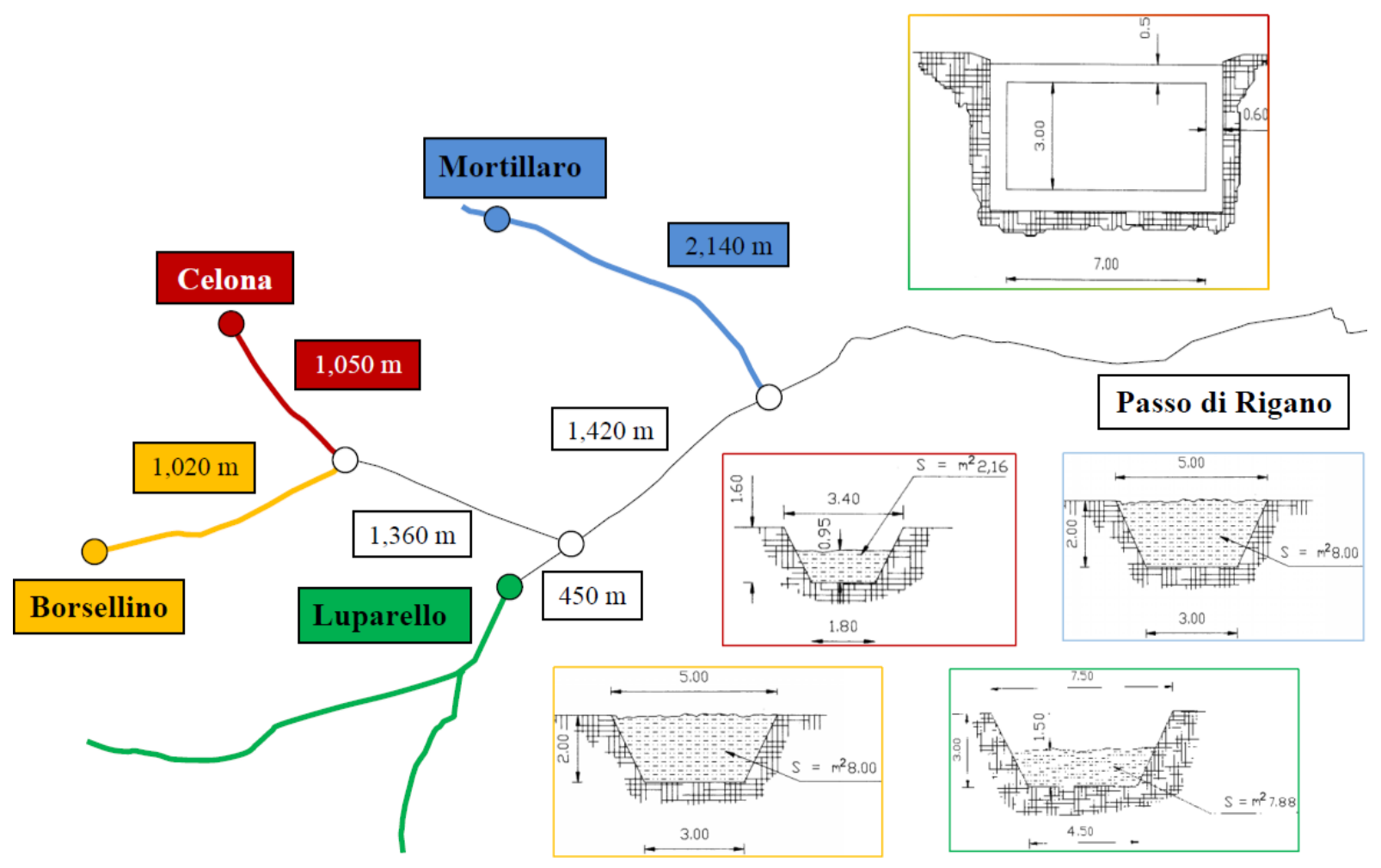

Figure 2. The Passo di Rigano drainage system for the conveying and regulating rainwater in the study area. The yellow color is associated with Borsellino, red with Celona, green with Luparello, and blue with Mortillaro channels; the box with mixed colors (red, yellow, and green) refers to the section of the Luparello channel downstream of the confluence with the Borsellino and Celona channels.

Celona, Borsellino, and Luparello. Apart from the Uditore rain gauge, located within the Uditore-Passo di Rigano district (cyan triangle in Fig. 3), other rain gauges very close to the study area are the Zootecnico and UIR (red triangles in Fig. 3) rain gauges, which are part of the rain gauge network of the Autorità di Bacino della Regione Sicilia (Basin Authority of the Sicilian Region; hereafter AdB), and the Bellolampo and OTT (green triangles in Fig. 3) gauges, which are part of the rain gauge network of the Department of Engineering of the University of Palermo (hereafter UNIPA).

During the last 15 years, the area has undergone a significant change in its urban environment due to the construction of a new mall in the northwestern part of the district, immediately downstream of the Celona basin outlet in Fig. 3, and a new tramline that traverses the entire district along the WSW-ENE axis. Both the interventions have increased the impervious areas within the district, thus exacerbating the effects of rainfall-runoff response of more severe precipitation events. Moreover, the tramline, which is bordered by sidewalks and walls, acts as a channel that conveys the stormwater and causes a faster propagation of the flood wave towards the Da Vinci underpass.

The hydraulic hazard and risk maps for the study area are reported in the Hydrogeological Setting Plan (Piano stralcio per l'Assetto Idrogeologico - PAI) for Sicily, which is a re- gional plan that maps the hydraulic and geomorphological hazard and risk for the Sicilian territory. The PAI shows the presence of a hydraulic hazard only for two small areas in the upper and central parts of the domain of study, which were scarcely affected by the flood studied here. In this case, the hazard map of the study, which dates to the early 2000s, was made by using a very simplistic approach just based on the position of the morphological depressions and without modeling any flooding dynamics in the study area.

\subsection{Overview of the most significant past flooding events}

Over the past 15 years, the Uditore-Passo di Rigano district has been affected by at least one flooding event per year. Figure 4 shows a collection of pictures of some of the most important events that occurred between 2009 and 2019. As it is possible to notice from these examples, all the events occurred between the end of summer and mid-fall as a consequence of convective rainfall events, which are typical of that period (Cipolla et al., 2020). Figure 4 also shows that the most-affected area of the district is usually the ring road of Palermo, along with its underpasses, since they act as collectors of the water conveyed by the via Leonardo Da Vinci, viale Michelangelo, and the tramline. The water that flows on the streets and the tramline generates fast flooding events 


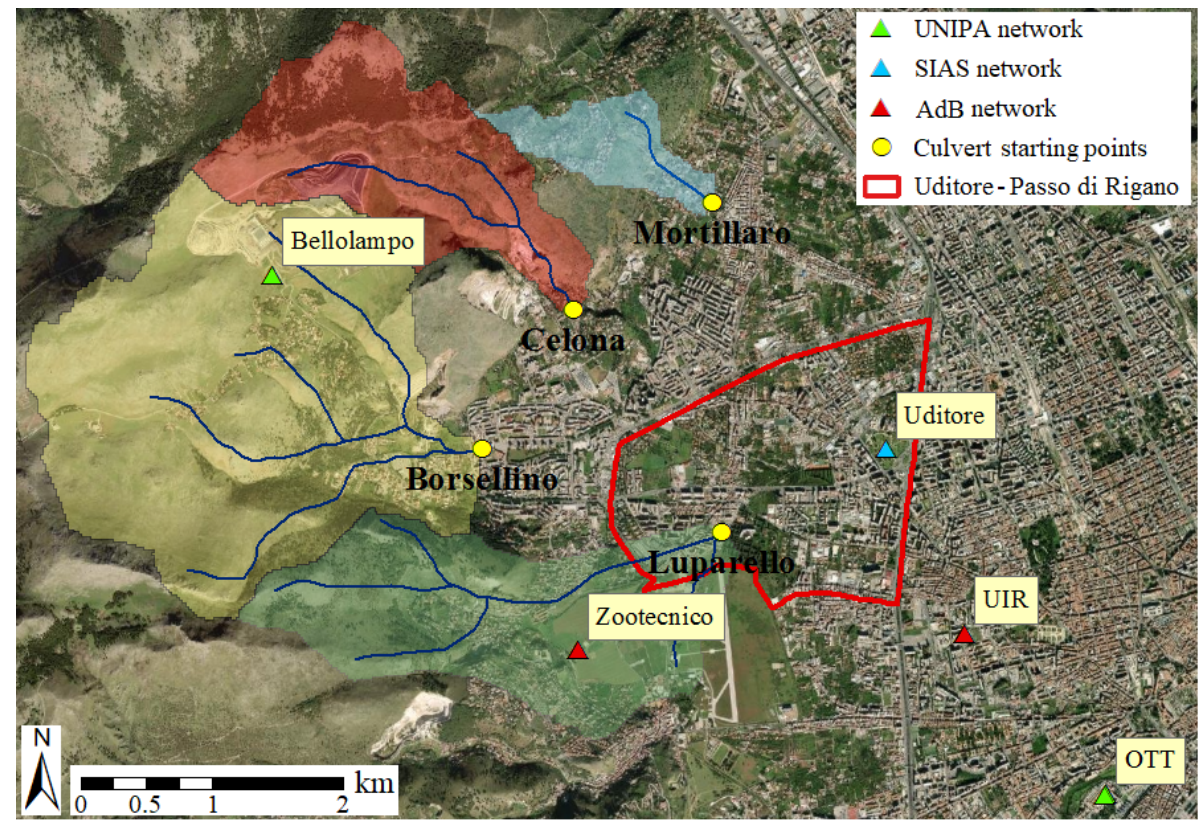

Figure 3. Main contributing catchments for the study area, i.e., Borsellino, Celona, Luparello, and Mortillaro. The yellow circles indicate the outlets of the contributing catchments and match with the starting points of the culverts. The red, cyan, and green triangles indicate the rain gauges of the basin authority (AdB), SIAS, and UNIPA networks, respectively. The red line indicates the Uditore-Passo di Rigano district. Source: (C) Google Maps Satellite basemap available within the QuickMapServices plugin of Quantum GIS.

that may cause considerable difficulties to drivers who often have no time to leave the ring road.

Figure 5 shows the hyetographs of the rainfall events associated with the flooding events reported in Fig. 4. All the events are relative to the rainfall collected at the Uditore rain gauge (red circle in Fig. 1). The duration of the events ranges between about $1.5 \mathrm{~h}$ (e.g., event of 6 October 2013) and about $4 \mathrm{~h}$ (e.g., event of 3 November 2018), with an instantaneous (i.e., $10 \mathrm{~min}$ ) intensity peak between $62.4 \mathrm{~mm} \mathrm{~h}^{-1}$ (e.g., event of 21 September 2009 and 3 November 2018) and $116.4 \mathrm{~mm} \mathrm{~h}^{-1}$ (e.g., event of 6 October 2013). All the events are characterized by a total rainfall higher than $40 \mathrm{~mm}$, with a maximum of about $60 \mathrm{~mm}$ during the event of 3 November 2018, and can be statistically classified as ordinary events with a return period ranging between 5 and about 20 years. The fact that even an ordinary rainfall event can generate a considerable flooding of the district is probably due to its high urbanization, which has completely upset the natural rain drainage network in that area, thus exacerbating the effects of the rainfall-runoff response.

\subsection{The precipitation event of 15 July 2020}

The severe storm that affected the city of Palermo on 15 July 2020 was the heaviest rainfall event recorded in the Palermo area during the last 90 years. It was due to a selfhealing supercell that remained in the same area for different hours, dumping a large amount of rainwater on it in a very short time. At the origin of the event, which assumed a marked oblique axis, there was a convergence line between the air coming from WNW and the sea breeze coming from NNE. At high altitude, this convergence line joined a strong instability area (region of positive vorticity advection) due to the passage of a trough on the Mediterranean Sea. This generated an intense updraft that favored the rapid cooling of the humid air coming from the sea. Moreover, the presence of hills and mountains close to the sea favored the downdraft of cold and dry air down to the sea, where the presence of warmer and humid air created the conditions for a new updraft that continuously fed the supercell. Figure S2 in the Supplement shows the self-healing thunderstorm cell observed around the 17:00 CET (Central European Time) on the city of Palermo from the visible channel of Meteosat-11 project satellites and provided by the EUropean Organisation for the Exploitation of Meteorological Satellites (EUMETSAT) of the UK Met Office.

The phenomenon was not easy to forecast; the Global Forecast System (GFS) model of National Centers for Environmental Prediction (NCEP) of the National Oceanic and Atmospheric Administration (NOAA) forecasted, between the 15:00 and 20:00 UTC, a cumulated rainfall in the range of 5-20 mm for some areas of the city of Palermo. However, from the observation of the synoptic pattern associated with the event, it was possible to deduce a risk of locally intense thunderstorm phenomena.

Figure 6 shows the geopotential heights of the $500 \mathrm{mbar}$ pressure surface (colored map in Fig. 6) and the MSLP (mean 

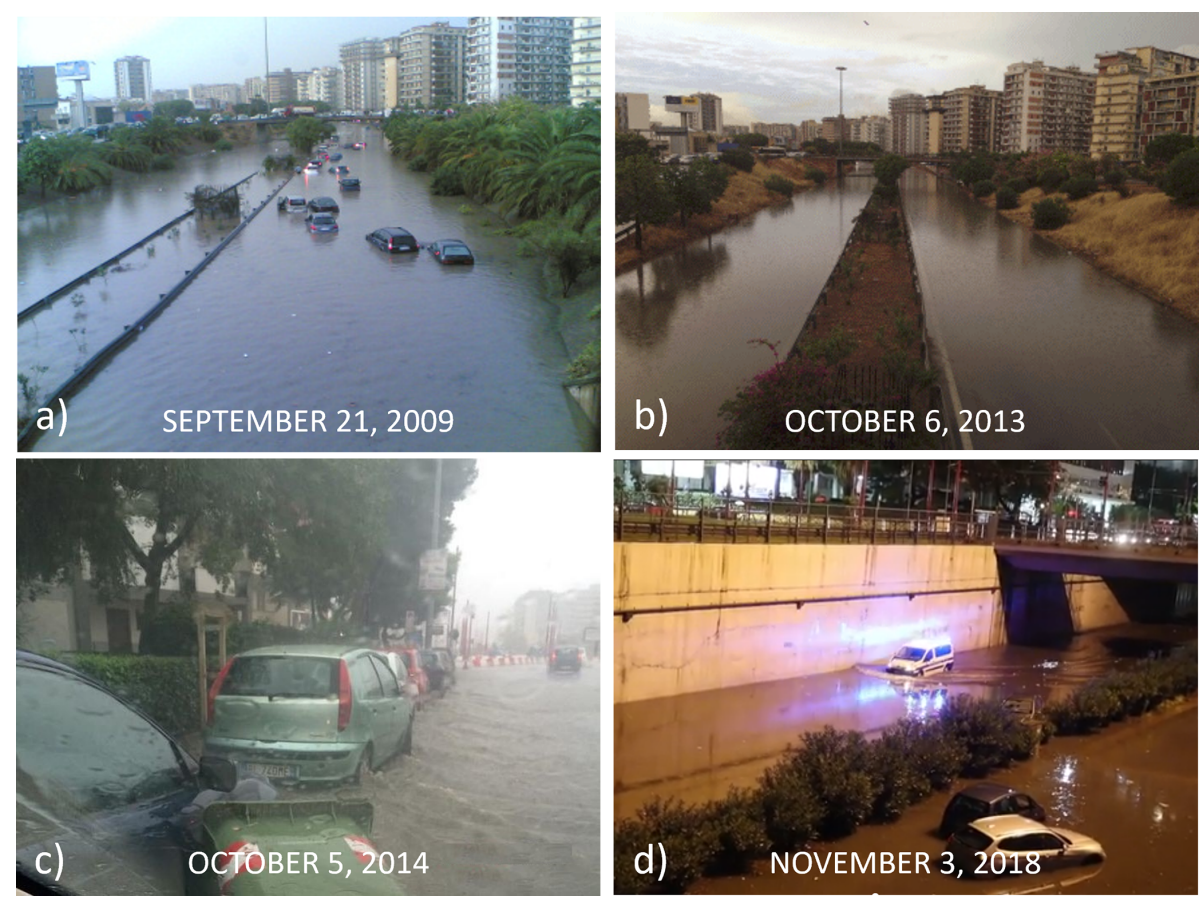

Figure 4. Flooding events that affected the Uditore-Passo di Rigano district on (a) 21 September 2009 , (b) 6 October 2013, (c) 5 October 2014, and (d) 3 November 2018. Source (a): Rosalio (https://www.rosalio.it/2009/09/22/ allagamenti-in-citta/, last access: 23 August 2021). Source (b): La Voce dell'Isola (https://www.lavocedellisola.it/2013/10/ palermo-nubifragio-in-corso-aerei-dirottati-viale-lazio-chiuso/, last access: 23 August 2021). Source (c): PalermoToday (https: //www.palermotoday.it/foto/cronaca/temporale-palermo-allagamenti-foto-5-ottobre-2014/via-leonardo-da-vinci-foto-antonio-rao.

html, last access: 3 March 2021). Source (d): Giornale di Sicilia (https://palermo.gds.it/video/cronaca/2018/11/04/ maltempo-a-palermo-strade-come-fiumi-e-auto-impantanate-il-video-di-viale-regione-allagata-8592631d-fcf3-4afe-a92c-db35376cd5ac/, last access: 23 August 2021).
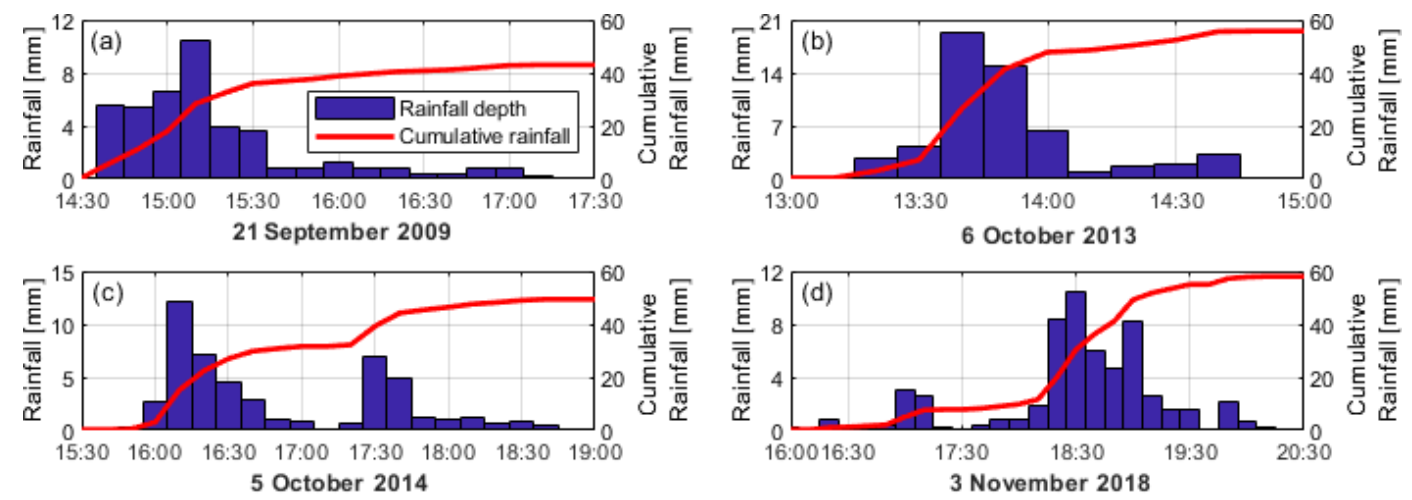

Figure 5. Rainfall collected at the Uditore rain gauge for the events occurring on (a) 21 September 2009, (b) 6 October 2013, (c) 5 October 2014, and (d) 3 November 2018.

sea level pressure; solid lines in Fig. 6) for 15 July 2020, as forecasted by the $12 \mathrm{z}$ GFS. From the analysis of Fig. 6, it is possible to observe a trough progressing southward, from Denmark to the Mediterranean Basin, with a strong positive vorticity advection quickly moving toward Sicily. The activity between the descendent trough from Denmark and the anticyclone from North Africa favored the ascent, up to Sicily, of a subtropical jet stream. These conditions of instability were further exacerbated by the positive values of potential vorticity, extending from the lower Mediterranean-Sardinian channel up to western Sicily, which injected further cold and dry air from the stratosphere.

The presence of a strong subtropical jet stream (around $300 \mathrm{hPa}$ ), cold and dry air (above $600 \mathrm{hPa}$ ), and very warm 


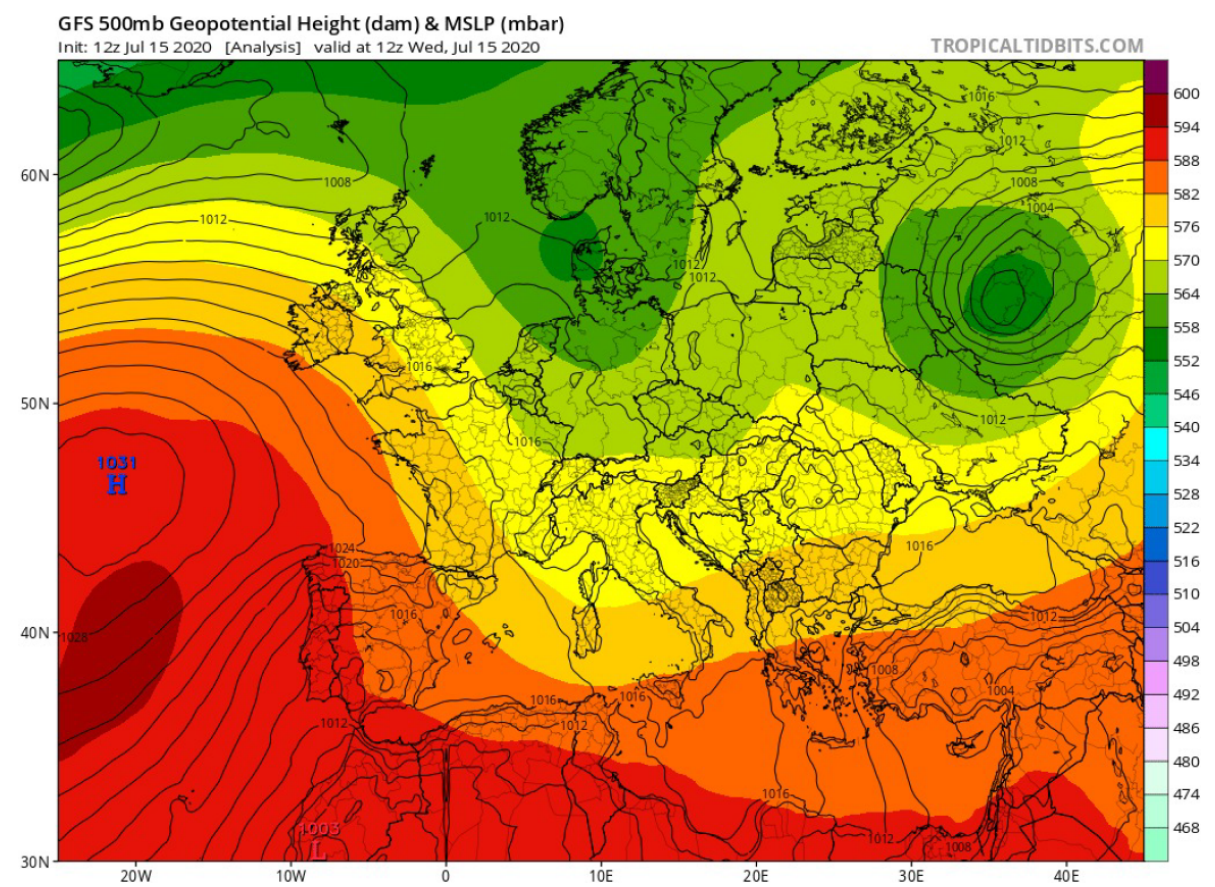

Figure 6. Geopotential heights at the 500 mbar level (12 z GFS) and mean sea level pressure (MSLP). Colored scale bar indicates the geopotential height values in dam (i.e., decameter), while black contour lines indicate MSLP in mbar (i.e., millibar). Source: NCEP (NOAA).

and humid air in lower layers are confirmed by the data recorded at the radiosonde data station at Trapani-Birgi (see Fig. S3).

The storm caused a very high intensity precipitation, especially over the Uditore-Passo di Rigano district (red line in Figs. 1 and 3) and the hilly/mountainous area around it, which started at around 16:00 UTC and lasted about $2 \mathrm{~h}$. On that occasion, the Uditore rain gauge (red circle in Fig. 1) of the regional agency SIAS (Servizio Informativo Agrometeorologico Siciliano - Agrometeorological Information Service of Sicily) reported a maximum hourly intensity of the event equal to $87.8 \mathrm{~mm} \mathrm{~h}^{-1}$, with an instantaneous intensity peak of $168 \mathrm{~mm} \mathrm{~h}^{-1}$ in $5 \mathrm{~min}$ at around 17:35 CET and a cumulative rainfall of $134 \mathrm{~mm}$ (Fig. 7a). Even without a robust statistical analysis made on the historical data, considering that this is the highest value ever recorded at the station since its installation (i.e., 2002) and that it represents the wettest day in July for the city of Palermo since 1797, much higher than the previous record (i.e., $39.2 \mathrm{~mm}$ on 6 July 1935), it is clear how the storm under analysis was not an ordinary rainfall event. Comparing the rainfall recorded for different accumulation periods with the annual maxima precipitation (AMP) for the same accumulation periods and recorded from 2002 through 2020 at the Uditore rain gauge, it is possible to notice how the precipitation on 15 July 2020 is much higher than the corresponding annual maximum values (e.g., $25.6 \mathrm{~mm}$ vs. $19.4 \mathrm{~mm}$ at $10 \mathrm{~min}, 87.8 \mathrm{~mm}$ vs. $48.2 \mathrm{~mm}$ at $1 \mathrm{~h}$, and $134 \mathrm{~mm}$ vs. $55.8 \mathrm{~mm}$ at $3 \mathrm{~h}$ ). Also, looking at the rainfall collected at the nearby UIR and Zootecnico rain gauges, which are characterized by a 48 - and a 40 -year time series, the precipitation of 15 July 2020 shows much higher values of depth at the durations of $1 \mathrm{~h}$ (i.e., $67 \mathrm{~mm}$ for the UIR station and $51.8 \mathrm{~mm}$ for the Zootecnico station) and $3 \mathrm{~h}$ (i.e., 85.4 for the UIR station and $99 \mathrm{~mm}$ for the Zootecnico station); the return period for both the 1 and $3 \mathrm{~h}$ rainfall durations, which has been estimated through the rainfall growth curves derived by Forestieri et al. (2018), resulted in values much higher than 200 years, thus highlighting the exceptionality of the rainfall event that occurred on that day in Palermo.

Similar rainfall depths were also recorded by the rain gauges nearby. Figure 7b-e show the hyetographs for the Zootecnico, UIR, Bellolampo, and OTT (see Fig. 3) rain gauges, respectively. As it is possible to notice, the Uditore (Fig. 7a), Zootecnico (Fig. 7b), and UIR (Fig. 7c) rain gauges show similar shapes of hyetographs, with two peaks ranging between $17 \mathrm{~mm}$ and about $21 \mathrm{~mm}$ at around 16:20 CET and about $24 \mathrm{~mm}$ and about $27 \mathrm{~mm}$ at around 17:30 CET, respectively, and a total rainfall depth between about 121 and $134 \mathrm{~mm}$ in total over the duration of the rainfall event. The Bellolampo (Fig. 7d) and OTT (Fig. 7e) rain gauges, despite still having a two-peak shape and a similar duration to the previous ones, instead show different values of peaks and lower total rainfall depths than the previous rain gauges. Moreover, the hyetograph related to the Bellolampo rain gauge (Fig. 7d) is shifted forward in time, suggesting that the supercell moved from the sea towards the mountains, show- 


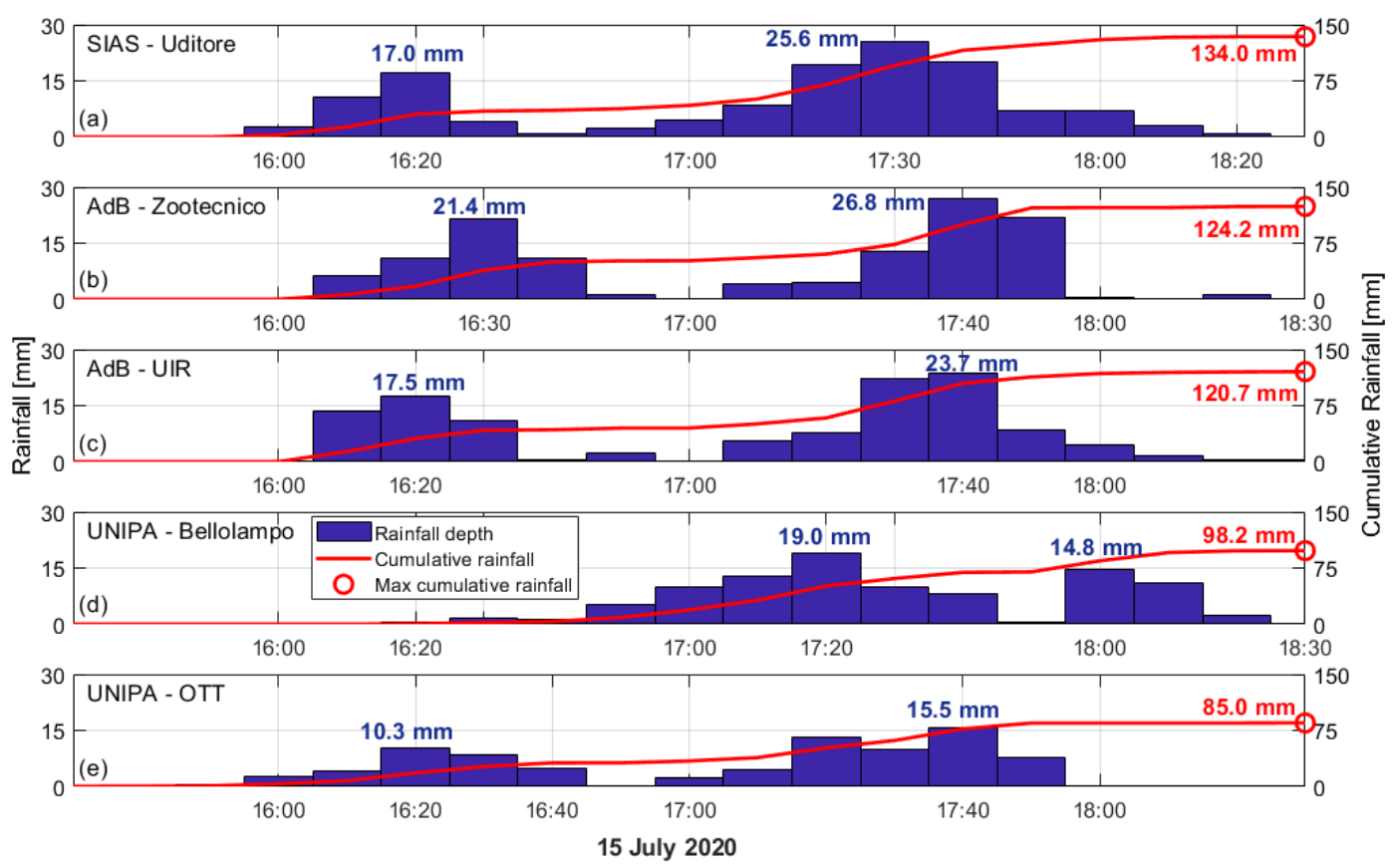

Figure 7. Rainfall collected at the rain gauges at (a) Uditore, (b) Zootecnico, (c) UIR, (d) Bellolampo, and (e) OTT on 15 July 2020 between 15:30 and 18:30 CET.

ing its exceptional nature, especially over the Uditore-Passo di Rigano district.

The result of such a precipitation event on a very highly urbanized area was the flooding of the ring road of Palermo and its underpasses, with damage to several cars and people being inconvenienced. In the Da Vinci underpass, as measured by the local fire department, the water level reached a depth of about $5 \mathrm{~m}$, with an estimated water volume of $28000 \mathrm{~m}^{3}$, trapping many drivers in their cars. Moreover, the precipitation caused some flash floods from the small hilly and mountain catchments around the Uditore-Passo di Rigano district that carried mud and debris from the slopes of the hills and mountains to the city. Although an exact quantitative estimation of the damages is still under evaluation, the regional government of Sicily has already allocated a first extraordinary contribution for damages of EUR 900 000; the amount includes EUR 350000 for damages to warehouses, shops, and production activities, EUR 250000 for vehicles, EUR 150000 for damage to furnishings, EUR 100000 for damages to homes, and EUR 50000 for physical damage to people.

\section{Material and methods}

This section presents hydrological and hydraulic models that were used for simulating the event that affected the UditorePasso di Rigano district. Both the models have been developed at the Department of Engineering of UNIPA. A brief description of the data used to verify the reliability of hydraulic model results is given as well.

\subsection{Hydrological modeling: the TOPDM}

The topography-based probability distributed model (TOPDM; Liuzzo et al., 2015; Noto, 2014) is a lumped conceptual model that allows the simulation, at basin scale, of all the hydrological processes of interest for the sort of flooding studied here. The model belongs to the family of the probability distribution models (PDMs; Moore, 1985), which represent the basin as a series of storages of capacity $c$. In particular, the TOPDM uses the spatial distribution of the topographic index to derive the probability distribution of the capacity of the considered storages. The model is capable of working at different temporal scales (i.e., from sub-hourly to daily); this makes the TOPDM suitable for simulating runoff and analyzing hydrological processes at the catchment scale, using a daily time step, or for simulating the flood forcing within the small Mediterranean basins, using an hourly or sub-hourly time step (Forestieri et al., 2016).

TOPDM conceptualizes the basin as two different bucket types, i.e., the soil moisture system, which is represented by a series of storages with capacity $c$, and the groundwater bucket, which interacts with the sub-surface system (i.e., soil moisture storage) and exclusively receives water volumes from it. Each storage in the soil moisture system can take water from rainfall and lose it by evaporation and/or vertical drainage, until one of the following conditions occurs: 
the storage fills and generates direct runoff, $q^{\prime}$, or empties and ceases to lose water by evaporation and vertical drainage. The complex process of evapotranspiration from the buckets is here indicated in its totality by the water lost. The storage capacity, $c$, is modeled as a random variable with a probability density function, $p(c)$. Therefore, that portion of basin characterized by a capacity ranging between $c$ and $c+\mathrm{d} c$ can be described as $p(c) \mathrm{d} c$.

According to the type of saturation mechanism in the soil column, the direct runoff from the soil moisture system (i.e., fast response) can be of two types, namely Hortonian or Dunnian. While the Dunnian runoff comes from a saturation excess mechanism, the Hortonian runoff, instead, occurs in the storages not yet saturated because of infiltration excess. Vertical drainage to groundwater, conceptualized by the model as a storage with unlimited capacity, is also simulated. This storage does not exchange water with the sub-surface system and generates the slow response (i.e., baseflow) of the basin. The fast response (i.e., surface runoff) of the system is routed to the basin outlet by means of a routing module based on the concept of the distributed unit hydrograph (Noto and la Loggia, 2007).

Estimation of the spatial distribution of the capacity is based on the catchment morphology through the topographic index, which is, as the capacity, an indicator of the catchment capability to produce runoff. The topographic index, $\lambda$, is expressed as follows:

$\lambda=\ln \left(\frac{\alpha}{\tan \beta}\right)$,

where $\alpha$ is the cumulative area drained through a unit length of contour line, and $\beta$ is the local surface slope. The probability distribution of the storage capacity is derived by assuming a linear relationship between topographic index $\lambda$ and storage capacity $c$ as follows:

$c=c_{\min }+\frac{\lambda_{\max }-\lambda}{\lambda_{\max }-\lambda_{\min }}\left(c_{\max }-c_{\min }\right)$,

where $c_{\min }$ is here set equal to 0 , and $c_{\max }$ is a model parameter. Equation (2) allows us to relate a high topographic index value to all those elements located along the network and characterized by a higher probability of saturation and a low topographic index value to those elements located on the hillslope. Once defined, the next step for the spatial distribution of $c$ is to fit on it a probability distribution. Here, a gamma distribution has been used as follows:

$p(c)=\left(\frac{c-\varepsilon}{\theta}\right)^{k-1} \frac{e^{-[(c-\varepsilon) / \theta]}}{\theta \Gamma(k)}$,

where the parameters $\theta, \varepsilon$, and $k$ derive from the mean, standard deviation, and skewness of the sample, respectively.

The model returns as output, in addition to the hydrograph at the outlet of the basin, different hydrological state vari- ables, such as the mean level of soil moisture within the watershed, the percentage of saturated area, the groundwater storage, and the potential and actual evapotranspiration.

For a complete description of the TOPDM, interested readers are referred to Noto (2014).

\subsection{Hydraulic modeling: the WEC-FLOOD}

The WEC-FLOOD (Filianoti et al., 2020; Sinagra et al., 2020) is a two-dimensional (2D) hydraulic model that solves the Saint-Venant equations to study the flood propagation within a 2D domain. The model is suitable for studies in urban areas, where the high complexity in the modeling of the surface runoff prompts, for the adoption of 2D models, a better simulation of the flooded areas (El Kadi Abderrezzak et al., 2009; Dottori and Todini, 2013; Lamb et al., 2009; Mignot et al., 2006). The use of the diffusive form, instead of the fully dynamic one, is mainly motivated by the smaller sensitivity of the computed water depth with respect to the topographic error (Aricò et al., 2011). The hydraulic 2D model (Aricò et al., 2011, 2016) in the diffusive form can be written as follows:

$$
\begin{aligned}
\frac{\partial H}{\partial t} & -\frac{\partial}{\partial x}\left(\frac{h^{5 / 3} \cos \alpha^{2 / 3}}{n \sqrt{|\nabla H|}} \frac{\partial H}{\partial x}\right) \\
& -\frac{\partial}{\partial y}\left(\frac{h^{5 / 3} \cos \alpha^{2 / 3}}{n \sqrt{|\nabla H|}} \frac{\partial H}{\partial y}\right)=Q,
\end{aligned}
$$

where $t$ is time, $H$ is the piezometric head, $h$ is the water depth, $\alpha$ is the bottom slope, $n$ is the Manning roughness coefficient, $Q$ is the source term, and $x$ and $y$ are the Cartesian directions. To make the model work properly, it is necessary to define the initial and boundary conditions for the domain (Eq. 4). Boundary conditions may be of the Dirichlet (prescribed piezometric head or water depth) or Neumann (prescribed flux) type.

The solution of the problem (Eq. 4) in the $H$ unknown is attained by means of a time-splitting approach named MAST (marching in space and time; Aricò et al., 2011) and solving for each time step consecutively in a convective prediction system (Eq. 5) and a diffusive correction system (Eq. 6) as follows:

$$
\begin{aligned}
\frac{\partial H}{\partial t} & -\frac{\partial}{\partial x}\left(\frac{h^{5 / 3} \cos \alpha^{2 / 3}}{n \sqrt{\left|\nabla H^{k}\right|}} \frac{\partial H^{k}}{\partial x}\right) \\
- & \frac{\partial}{\partial y}\left(\frac{h^{5 / 3} \cos \alpha^{2 / 3}}{n \sqrt{\left|\nabla H^{k}\right|}} \frac{\partial H^{k}}{\partial y}\right)=Q
\end{aligned}
$$




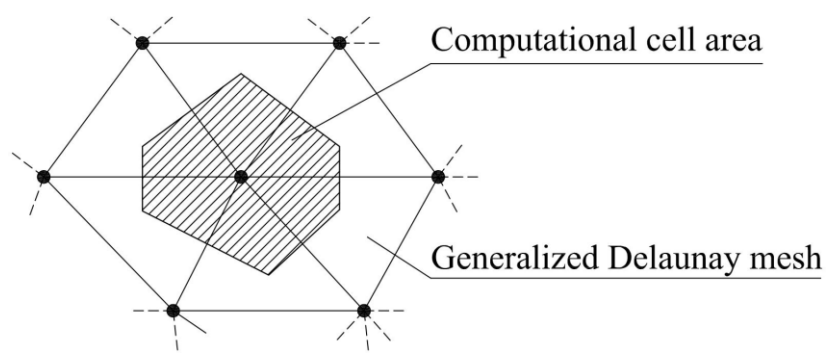

Figure 8. Computational mesh of WEC-FLOOD model. The vertices of each cell (black dots) are the computational centers of the cells (i.e., the point at which the water surface is computed for the cell) and are obtained as the circumcenters of the generalized Delaunay triangulation.

$$
\begin{aligned}
\frac{\partial \eta}{\partial t} & -\frac{\partial}{\partial x}\left(\frac{\left(h^{k m}\right)^{5 / 3} \cos \alpha^{2 / 3}}{n \sqrt{\left|\nabla H^{k}\right|}} \frac{\partial(\eta-\vartheta)}{\partial x}\right) \\
- & \frac{\partial}{\partial y}\left(\frac{\left(h^{k m}\right)^{5 / 3} \cos \alpha^{2 / 3}}{n \sqrt{\left|\nabla H^{k}\right|}} \frac{\partial(\eta-\vartheta)}{\partial y}\right)=0
\end{aligned}
$$

where $\eta=H-H^{k+1 / 2}, \vartheta=H^{k}-H^{k+1 / 2}$, and $h^{k m}$ is a water depth value in the computational cell (Fig. 8) obtained by local mass balance. It is worth observing that the formulation of Eq. (5) differs from the original one (Eq. 4) in the time level of spatial gradients of $H$, in which the prediction steps are kept constant in time and equal to the values computed at the end of the previous time step. The reader is referred to the original papers for more details.

The spatial discretization of the 2D domain is performed with an unstructured triangular mesh, satisfying the generalized Delaunay conditions (Aricò et al., 2011). The source term $Q$ in Eq. (4) is given either by the net rainfall intensity, which is integrated over all the cell area (Fig. 8), or by the storm hydrograph, if the cell is a boundary cell.

\subsection{Crowdsourced data}

One of the main difficulties when evaluating the reliability of hydraulic simulations in urban areas is the absence of measured water depth values to be used for the validation of results. To overcome this problem, many studies have used crowdsourced data to analyze flood events (Annis and Nardi, 2019; Mazzoleni et al., 2015, 2018; Smith et al., 2017; Yu et al., 2016).

Considering the high population density that characterizes the city of Palermo in the proximity of the viale Regione Siciliana, and that it is a very busy road, especially during the summer period, the flood occurring on 15 July 2020 was photographed and filmed by many social network users.

Data (e.g., videos and pictures) from YouTube and online local magazines (e.g., PalermoToday, Giornale di Sicilia, Live Sicilia, La Voce dell'Isola, etc.) were used to verify the reliability of the hydraulic modeling results, above all in correspondence with viale Regione Siciliana and the Da Vinci and Michelangelo underpasses, which were the most affected areas of the investigated domain. The georeferencing of the images was possible by matching the crowdsourced data with information gathered from Google Street View.

\section{Results and discussion}

This section presents the results of the numerical reconstruction of the flooding event that affected the city of Palermo on 15 July 2020 that arose from the modeling framework proposed in this study. In particular, the hydraulic forcing to be propagated within the study area consists of the hydrographs simulated at the outlets of the four contributing catchments (yellow circles in Fig. 3) with the TOPDM. The hydrographs were propagated within the study area with WEC-FLOOD to simulate the flood map for the event under study.

\subsection{Hydrological modeling}

The spatial distribution of the topographic index $\lambda$ was derived from the $2 \mathrm{~m}$ resolution digital elevation model (DEM) data of the study area (Fig. 3) with the single flow direction algorithm (SFD; O'Callaghan and Mark, 1984). The DEM is available at the SITR (Sistema Informativo Territoriale Regionale della Sicilia - Geographical Information System of Sicily). $\lambda$ was used to derive the specific contributing area and the slope of each catchment with the Wolock-McCabe method (Wolock and McCabe, 1995). The grid cells with a null value of the slope, which would make the $\lambda$ calculation impossible, were replaced by very small values of the slope. By these calculations, the areas characterized by the highest values of the topographic index are located along the drainage network. The relative frequency of the topographic index has been used to derive the spatial distribution of the storage capacity, $c$, using Eq. (2), while a three-parameter Gamma distribution has been fitted to the distribution of $c$ through Eq. (3).

Rainfall data collected at the Uditore, Zootecnico, UIR, Bellolampo, and OTT (see Fig. 3) rain gauges were interpolated with the inverse distance weighted (IDW) method to provide the spatial rainfall field over the study area; the distributed rainfall was then used to obtain the rainfall forcing, at the catchment scale, of the hydrological model.

The Passo di Rigano drainage system was supposed to be in a perfect condition of maintenance, even though its actual state is not known because of its complexity. The information provided by the municipality of Palermo was used to set the maximum discharge (i.e., channel capacity) for the Borsellino, Celona, Luparello, and Mortillaro channels equal to $40,14,25$, and $11 \mathrm{~m}^{3} \mathrm{~s}^{-1}$, respectively. These channel capacities were then subtracted from the simulated hydro- 


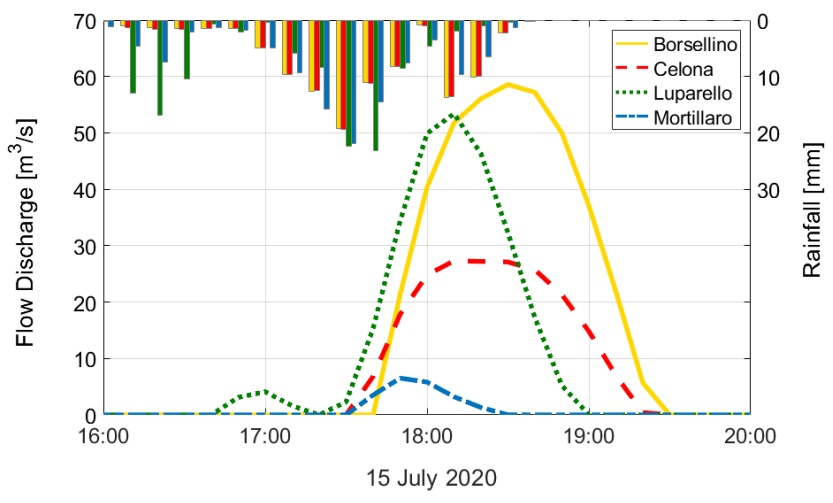

Figure 9. Flow discharge obtained from the hydrological simulations in TOPDM. The bars in the upper part of the figure indicate the IDW interpolated precipitation over the four basins.

graphs and were supposed to be conveyed downstream of the study area by the culverts.

Figure 9 shows the flow hydrograph for each channel after the subtraction of its channel capacity. As it is possible to notice from Fig. 9, as compared to the Borsellino, Celona, and Luparello hydrographs, the contribution of the Mortillaro basin is very small (i.e., hydrograph peak about $6 \mathrm{~m}^{3} \mathrm{~s}^{-1}$ ) since its channel capacity can intercept almost the entire hydrograph.

\subsection{Hydraulic modeling}

\subsubsection{The domain reconstruction}

The digital reconstruction of the hydraulic computing domain was carried out using the $2 \mathrm{~m}$ resolution DEM provided by the SITR. The complexity of the urban area required an improvement of the built-up environment by manually inserting the plano-altimetric trend of the elements that may affect flow direction, such as traffic islands, the tramline, buildings, and underpass roads (green and orange elements in Fig. 10), not reproduced by the DEM model. The study area has a surface of $9.2 \mathrm{~km}^{2}$ and is very irregular due to its high anthropization.

According to the outline and the constrained elements inside the domain, a computational mesh of 771018 elements and 412919 nodes was generated. The resulting mean length of the triangle sides is between 3 and $8 \mathrm{~m}$. A null water depth was assumed to be the initial condition. The discharge hydrographs of the basins named Borsellino, Celona, Luparello, and Mortillaro, simulated with the TOPDM (Fig. 9), were assigned as inlet boundary conditions and then propagated within the domain of study with the hydraulic model. Moreover, precipitation over the entire domain was obtained from the interpolated rainfall field. A zero-diffusion condition was assigned to the outlet boundary (blue line in Fig. 10). Particular attention has been paid to the choice of the roughness coefficient to be used for the simulations; two different
Manning coefficient values have been adopted for urban and natural areas (Chow, 1959), with values equal to 0.03 and $0.05 \mathrm{~s} \mathrm{~m}^{-1 / 3}$, respectively.

\subsubsection{D urban flood simulation}

The numerical results from the hydraulic model in some of the most affected areas during the flood under analysis were compared with specific reports, crowdsourced data, and satellite images to assess the goodness of the simulations.

Figure 11 shows the map of the flooded areas returned by the simulations in WEC-FLOOD. The results show a good agreement with what happened on that day, based on the fire department reports, images, videos, and interviews collected from the web that were shared by people on that day. As it is possible to notice from Fig. 11, most of the UditorePasso di Rigano district (see the red polygon in Figs. 1 and 3) was flooded. The most-affected areas were the streets within the district and the tramline, which turned into a river that finished as waterfall in the Da Vinci underpass (picture 1 in Fig. 12). It was precisely the Da Vinci underpass (box 1 in Figs. 11 and 12), along with the Michelangelo underpass (box 2 in Figs. 11 and 13), that formed the most critical area on 15 July 2020.

Figures 12 and 13 show the results of simulations in WECFLOOD for the Da Vinci and Michelangelo underpasses, respectively. During the flood event, the two underpasses worked as two reservoirs, where the water depth reached values higher than $4 \mathrm{~m}$. Also in this case, it is possible to notice a good qualitative match with the historical pictures taken from the people in the Da Vinci (Fig. 12) and Michelangelo (Fig. 13) underpasses. The simulation returned water depths of about 3.2 and $5.0 \mathrm{~m}$ in points 1 and 2 of Fig. 12, respectively, which are totally compatible with values reported by the fire department (i.e., between 4.5 and $5.0 \mathrm{~m}$ in the deepest point of the Da Vinci underpass). With reference to the Michelangelo underpass, the model returned water depths of about $1.5 \mathrm{~m}$ in points 1 and 2 and about $2.3 \mathrm{~m}$ in point 3 of Fig. 13, which are compatible with the water levels shown by the pictures.

In order to make a further evaluation of the goodness of the results in terms of flooded area extent, these have been qualitatively compared with images provided by the Copernicus Sentinel-2 project (Drusch et al., 2012) of the European Space Agency (ESA) for 16 July 2020 at around 09:50 UTC and limited to the areas of the Da Vinci and Michelangelo underpasses. The Sentinel-2 images of 14 July 2020 at around 10:00 UTC (i.e., the day before the flooding event) and 16 July 2020 at around 10:00 UTC (i.e., the day after the flooding event) are reported in the Supplement (see Fig. S4a and b, respectively). In particular, Fig. S4b reveals the traces left by the mud the day after the flooding event in the two underpasses, which are compatible with the extension of the flooded area returned by the WEC-FLOOD numerical simulations. 


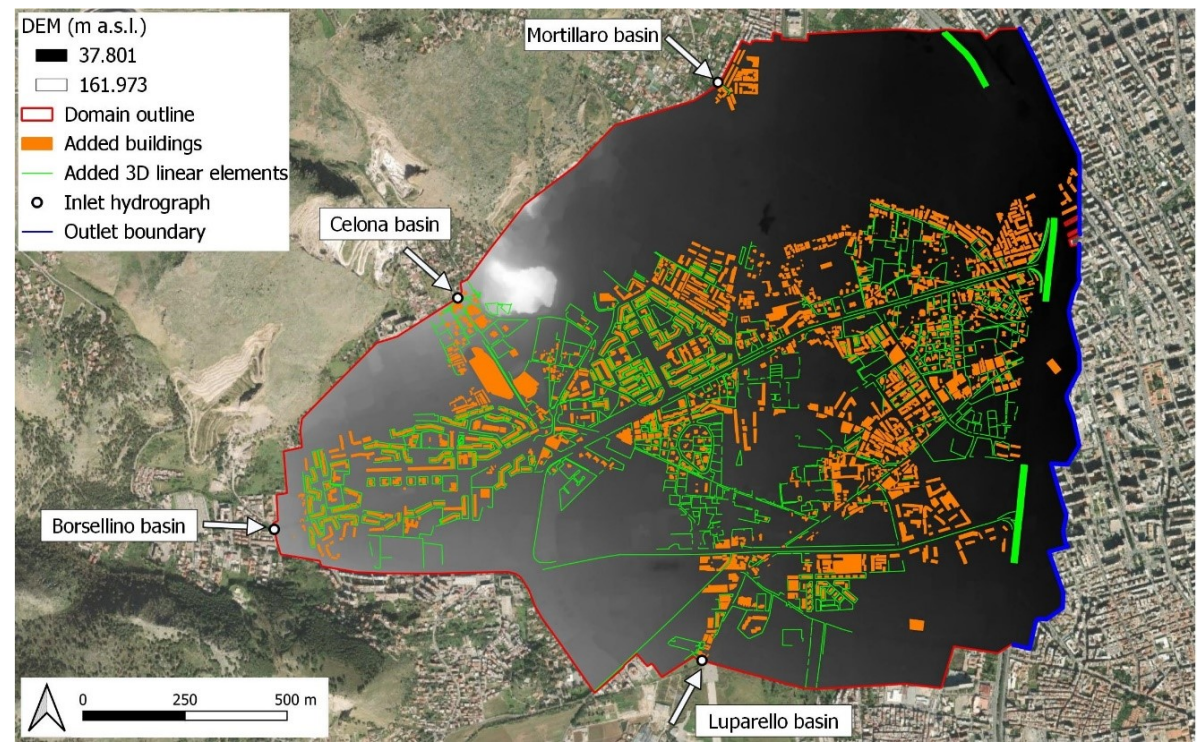

Figure 10. Domain reconstruction for the 2D hydraulic simulation in WEC-FLOOD. Source: () Google Maps Satellite basemap available within the QuickMapServices plugin of Quantum GIS.

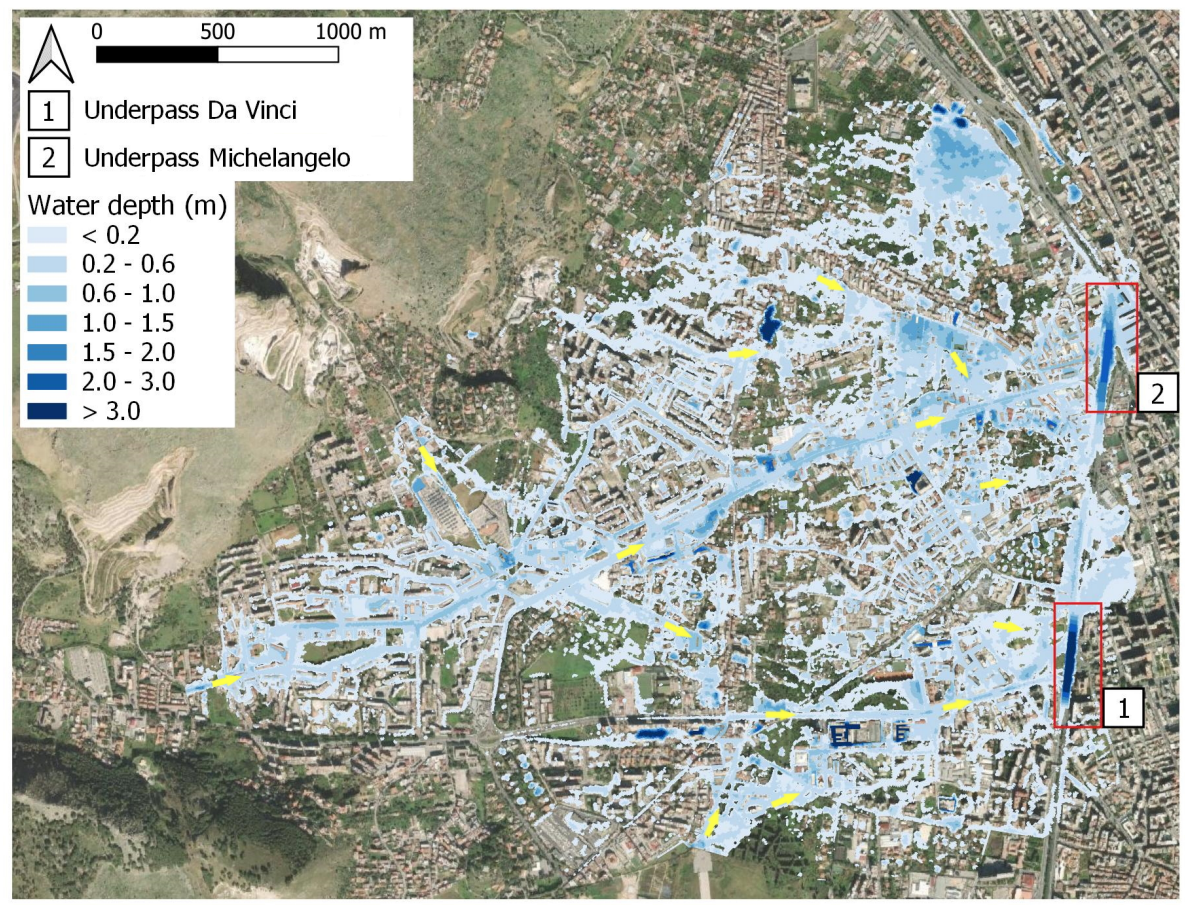

Figure 11. Map of the maximum flood depths reached on 15 July 2020 for the Uditore-Passo di Rigano district as simulated in WEC-FLOOD. The yellow arrows indicate the flow directions of the flood. Source: () Google Maps Satellite basemap available within the QuickMapServices plugin of Quantum GIS.

\subsection{Future directions in urban stormwater management}

Effective assessment and management of the hydraulic risk in an urban context should be the result of a well-balanced and dynamic development of all the essential components of a protection system that includes accurate activities of forecast and assessment of the risk, the adoption of adequate prevention and protection measures, and a correct residual risk management. 


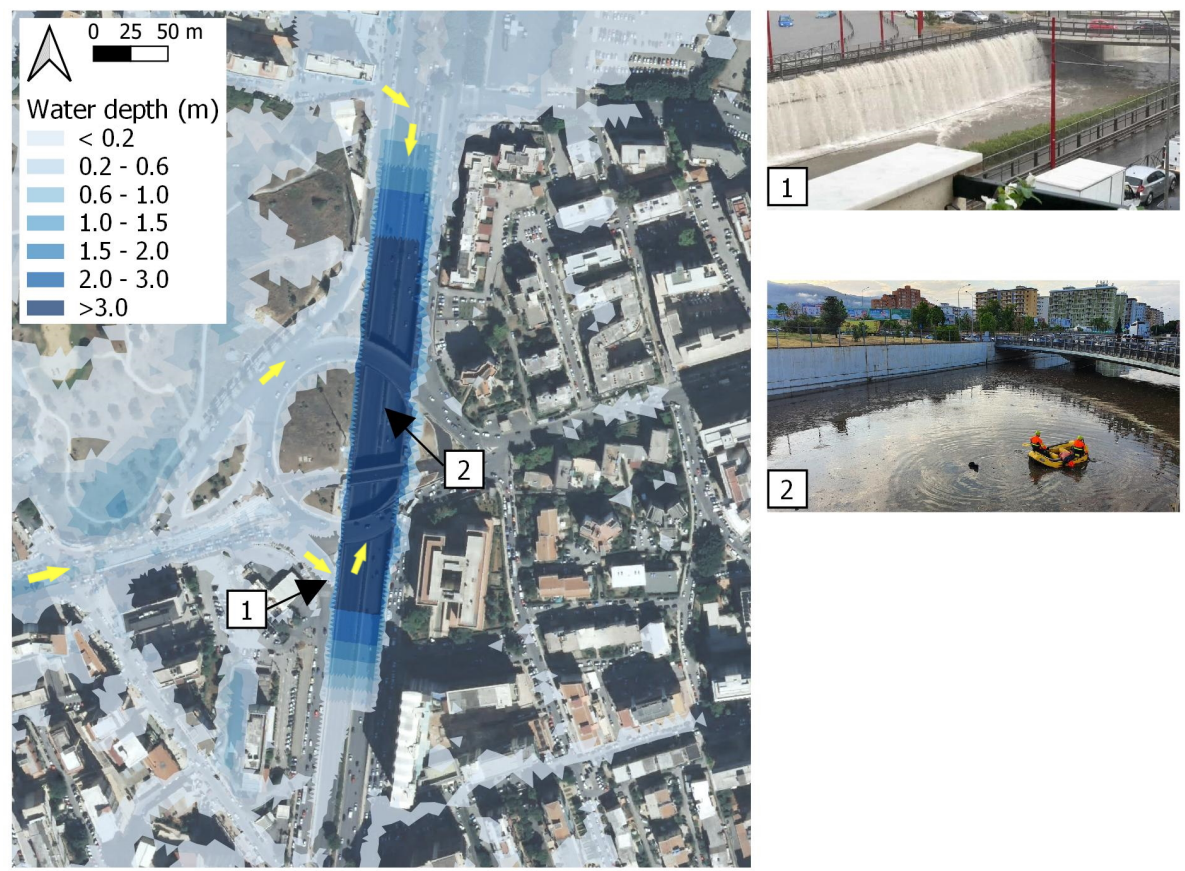

Figure 12. Maximum flood depths for the Da Vinci underpass as simulated in WEC-FLOOD. The yellow arrows indicate the flow directions of the flood. Source: (C) Google Maps Satellite basemap available within the QuickMapServices plugin of Quantum GIS. Source picture 1: PalermoToday (https://www.palermotoday.it/cronaca/nubifragio-palermo-15-luglio-2020.html, last access: 23 August 2021). Source picture 2: Monreale Press (https://www.monrealepress.it/2020/07/15/tragedia-in-viale-regione-morte-quattro-persone-nei-sottopassi/, last access: 23 August 2021).

The increasing availability of accessible crowdsourced information, along with more accurate hydrological and hydraulic models, suggests new approaches in urban flood modeling, highlighting the importance of developing frameworks capable of doing the following:

1. producing reliable reconstructions of occurred events and mapping particularly vulnerable areas;

2. using crowdsourced data, considering that satellite data are not always adequate for obtaining observations during (or after) such critical events (see, for instance, Fig. S4) and are often not timeously available because of the satellite orbit revisit time;

3. forecasting, in near-real time, the potential effects of incoming rainfall and, consequently, selecting adequate mitigation strategies; and

4. running multi-scenario simulations during the urban expansion planning phase to preliminarily evaluate the effects of both new urban expansions, including gray, green, and blue infrastructures, and possible alternative interventions on the urban drainage systems to adapt cities to the future hydraulic risks.

In areas particularly susceptible to pluvial and flash floods, it is extremely important to enhance the capability of rain- fall monitoring and early flood warning in order to take appropriate civil protection actions (e.g., closure of roads and underpasses, warnings to the population, etc.). However, as it has been shown in this study, sometimes the rainfall event causing an urban flood can be extremely difficult to forecast due to its very fast emergence and intrinsic morphometric characteristics of the area. In such a case, the real-time monitoring of the flood event (e.g., real-time observation of water levels and precipitation in some strategic points or locations) could be an important option to drive emergency actions and reduce the potential flood damages.

In this regard, after the urban flood event of 15 July 2020, the municipality of Palermo and the integrated water service company of AMAP S.p.A. planned the realization of a realtime monitoring network, including seven water level sensors and cameras installed at different strategic and particularly vulnerable sites over the city; two of these sensors have already been installed in the Da Vinci and Michelangelo underpasses and are connected to traffic lights, opportunely installed over the ring road of Palermo, to inhibit the vehicular transit when a prefixed threshold water level in the underpasses is exceeded. Such a measure could probably have significantly reduced the damage for vehicles during the flood of 15 July 2020 and, in general, could considerably reduce the risk of mortality, considering that more than half of the fatalities attributed to flash floods (i.e., $56.1 \%$ ) in the 50- 

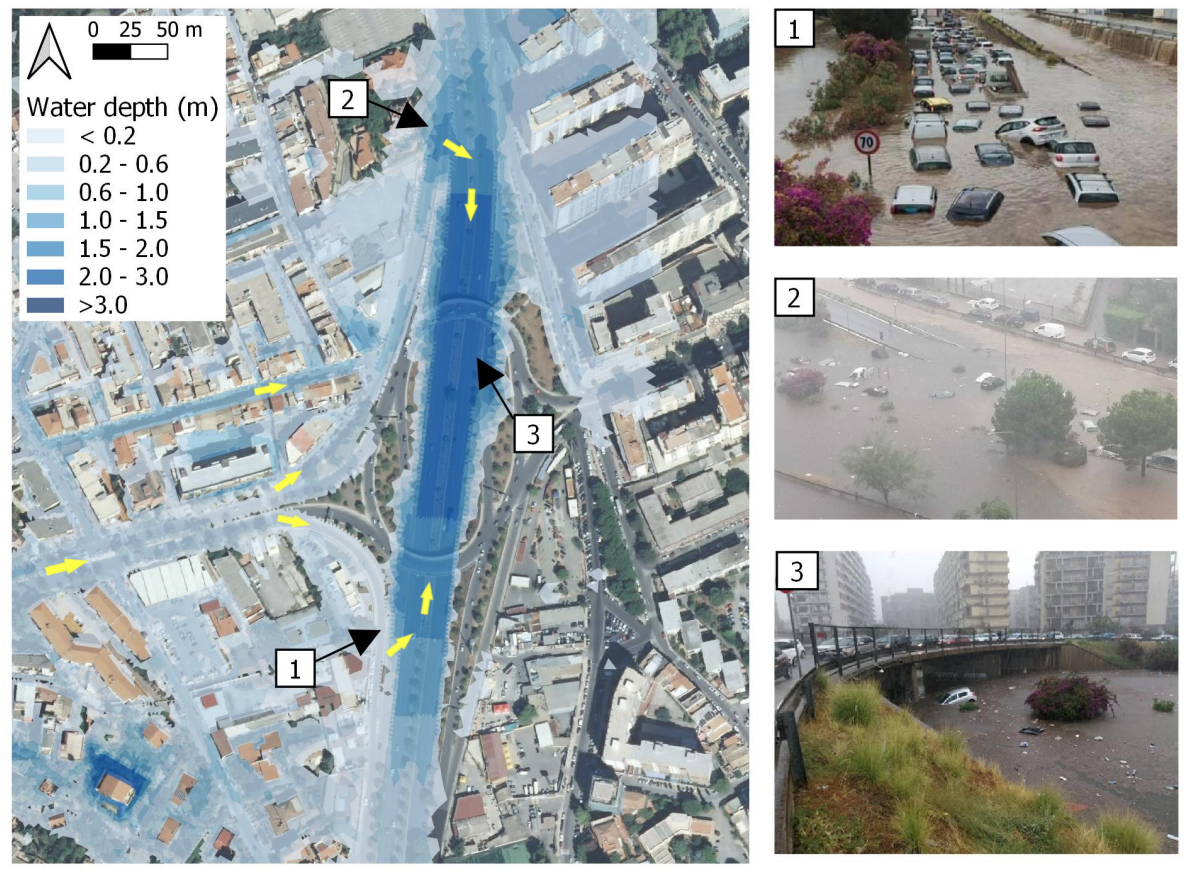

Figure 13. Maximum flood depths for the Michelangelo underpass as simulated in WEC-FLOOD. The yellow arrows indicate the flow directions of the flood. Source: () Google Maps Satellite basemap available within the QuickMapServices plugin of Quantum GIS. Source picture 1: PalermoToday (https://www.palermotoday.it/foto/cronaca/allagamento-palermo-15-luglio-2020-foto/ \#allagamento-festino-2020-viale-regione-4.html\&gid=1\&pid=1, last access: 23 August 2021). Source picture 2: La Repubblica Palermo (https://palermo.repubblica.it/cronaca/2020/07/15/news/palermo_-262015602/, last access: 23 August 2021). Source picture 3: StrettoWeb (http://www.strettoweb.com/foto/2020/07/maltempo-sicilia-alluvione-palermo-morti-dispersi-bambini-ipotermia-foto/1037325/, last access: 23 August 2021).

year period (1965-2014) in Italy are car related (Salvati et al., 2018).

Nowadays, it is important to point out the need to pay greater attention to the development/modification of urban areas, where the alterations induced on the soil properties must be accompanied by an integrated planning system for the assessment of future risk and aiming to find new paths towards the risk adaptation of smart, sustainable, and floodresilient cities. In highly urbanized areas, where modifications to the existing urban drainage system are difficult and under a climate change context, with more frequent heavy rainfall events, it is necessary to shift towards a new way of managing the hydraulic risk and adapting cities to it.

There is, therefore, the need for a new paradigm capable of proposing solutions that are changeable according to the rainfall event that is causing the flooding event. In this regard, several studies (Ahiablame et al., 2013; Liu et al., 2014; Zahmatkesh et al., 2015) have demonstrated the effectiveness of best management practices (BMPs) and solutions inspired and supported by nature, i.e., the so-called natural-based solutions (NBSs), in significantly reducing runoff volumes and peak discharges and increasing the times to the peak of an urban flooding. In this regard, it would be possible to plan the use of sparsely distributed NBSs and BMPs, such as ur- ban green areas, green roofs, pervious pavements, or rainfall harvesting systems, which could contribute to mitigating the effects of rainfall-runoff response of ordinary rainfall events, with a return period comparable to that used to design the drainage system, while solutions such as the urban flood retention basins may be suitable for reducing the effects of more severe rainfall, with return period which is slightly higher than that characteristic of the urban drainage system.

For extraordinary rainfall events, such as the one that has caused the event of Palermo investigated here, the only solutions that could contribute to reducing damages and risks are probably those oriented to the concept of floodability (La Loggia et al., 2020), which is based on the concept that flooding can be tolerated by the society and has to be viewed as a driver for societal development. A floodable system is a well-informed aggregation of resistant, resilient, and floodable subsystems in which people are the key actors. In such a system, people are instructed and trained to prepare themselves and adapt their properties and activities to the possibility of flood events and then to "live with floods". A learningby-doing process is adopted to make the population able to adapt its strategies to the evolution of events and then also to face unexpectedly severe events. Moreover, the involvement of other actors, such as public bodies, citizen organi- 
zations, professional associations, commercial and industrial corporations, and technical experts, support the integration of structural mitigation measures with individual and coordinated actions that result in a reduction in cities' vulnerability and an improvement of the society's adaptivity.

Such a new paradigm probably requires a change in the aesthetic convention by which the only purpose of parks and playgrounds is recreation. Indeed, instead of assigning recreation as the exclusive use of parks, these could be designed to serve as temporary storage areas to fulfill hydrological roles. Open spaces could thus become spaces for restoring the damage done by excessive urban development, both in terms of hydrology and architecture, thus making it possible to adapt cities to future risk.

\section{Conclusions}

This study reproduces the dynamics and impacts of a recent urban flood that affected the city of Palermo (Sicily, Italy), mainly focusing on the analysis of the precipitation event that caused it, which can be classified as an extraordinary event, and the hydrological and hydraulic modeling framework necessary to correctly simulate its effects on rainfall-induced runoff response. According to the last report released by IPCC (Intergovernmental Panel on Climate Change; 2019), climate change and global warming are significantly changing the frequency of these types of events, which are becoming the new normal in the Mediterranean area; this is leading to an increased occurrence of short duration rainfall extremes that have caused landslides and floods in the last few decades (Yin et al., 2018). Moreover, the rapid and progressive urbanization, especially for larger cities with important historical centers, with continuous losses of natural soil and substantial modifications to natural drainage systems, is profoundly altering the effects of the rainfall-runoff response of heavy precipitation on urban areas, often with dramatic consequences. In this regard, the case study investigated here, due to the precipitation characteristics, effects of rainfall-runoff response, flooding dynamics, and degree of urbanization, can be considered as representative of what many cities in the Mediterranean area may have to deal with in the near future.

The flooding event has been simulated using a cascading hydrological and 2D hydraulic model, and the results have been validated through a qualitative comparison with crowdsourced information and some satellite post-event images. The hydraulic model has shown relevant performances in reproducing the flooding under analysis, as demonstrated by the qualitative comparison with reports, pictures, and satellite images acquired during and after the event. The crowdsourced data, which represent a new frontier to improve the observation, understanding, and modeling of floods, especially in an urban area, where the enormous and increasing diffusion of mobile devices (e.g., smartphones, tablets, etc.) makes it possible to acquire real-time and no cost monitor- ing of both rain and flood events, have made possible to verify the reliability of the hydraulic model by means of reports and hundreds of pictures and videos found on social media. In this regard, the modeling framework here developed can be assumed to be a paradigm for the modeling of extreme rainfall pluvial floods in complex urban areas.

The study of the event of 15 July 2020 has pointed out that the city of Palermo, with its long track of history - as with many cities in the world - cannot plan the design of new, larger sewer pipes that pass under the city or the construction of flood diversion channels that drain the water coming from the upstream-contributing basins. There is, therefore, the need to implement some new ideas such as the one of floodability. Floodable cities are able to avoid physical damage and socioeconomic disruption during a flood. Due to this feature, floodable cities are more than resilient because their systems do not aim to return to their pre-existing equilibria quickly and efficiently but to adapt and find new equilibria in which flooding is an event "to live with". As a matter of fact, change cannot be solely technical or infrastructural when considering that services, functions, land use, and infrastructure will change and may be different in the steady state (i.e., when the flood is not happening) compared to when they are in the event state (i.e., during flooding); therefore, change must involve an entire society.

Thus, water and urban planning integration can be considered as the keys needed to develop useful strategies that are able to make cities resilient and floodable. Floodability does not introduce new mitigation measures; rather, it provides a new perspective through which it is possible to combine existing measures in a framework that incorporates societal, economic, environmental, and technical aspects, as demonstrated for the city of Palermo.

Code availability. The TOPDM model is available upon request by contacting the corresponding author directly by email. The WEC-FLOOD model was developed by the WECONS (Water Engineering CONSulting) and is not publicly accessible. Currently, the WECONS is working to develop an open-source version of the model. For more information, please visit https://www. wecons.it/ (last access: 23 August 2021; WECONS, 2021) or contact Marco Sinagra directly by email (marco.sinagra@unipa.it or m.sinagra@wecons.it).

Data availability. The authors collected original precipitation data from different sources. The original data are available upon request by contacting the corresponding author directly by email.

Supplement. The supplement related to this article is available online at: https://doi.org/10.5194/nhess-21-2563-2021-supplement. 
Author contributions. AF did the data collection and analysis, hydrological simulations, reconstruction of the most significant past flooding events for the case study, and results analysis and wrote the original draft and reviewed and edited the paper. DP performed the climatic reconstruction of the event of 15 July 2020 and the results analysis and wrote, reviewed, and edited the paper. MS conducted the hydraulic simulations and wrote, reviewed, and edited the paper. GLL also conducted the results analysis, commented on future urban stormwater management, and reviewed and edited the paper. LVN supervised and wrote, reviewed, and edited the paper.

Competing interests. The authors declare that they have no conflict of interest.

Disclaimer. Publisher's note: Copernicus Publications remains neutral with regard to jurisdictional claims in published maps and institutional affiliations.

Special issue statement. This article is part of the special issue "Future risk and adaptation in coastal cities". It is not associated with a conference.

Acknowledgements. The authors would like to thank the reviewers for their thoughtful comments and efforts towards improving the original paper.

Review statement. This paper was edited by Paolo Tarolli and reviewed by Francisco Peña and one anonymous referee.

\section{References}

Ahiablame, L. M., Engel, B. A., and Chaubey, I.: Effectiveness of low impact development practices in two urbanized watersheds: Retrofitting with rain barrel/cistern and porous pavement, J. Environ. Manage., 119, 151-161, https://doi.org/10.1016/j.jenvman.2013.01.019, 2013.

Andersson-Sköld, Y. and Nyberg, L.: Effective and Sustainable Flood and Landslide Risk Reduction Measures: An Investigation of Two Assessment Frameworks, Int. J. Disast. Risk Sci., 7, 374392, https://doi.org/10.1007/s13753-016-0106-5, 2016.

Annis, A. and Nardi, F.: Integrating VGI and 2D hydraulic models into a data assimilation framework for real time flood forecasting and mapping, Geo-Spat. Inform. Sci., 22, 223-236, https://doi.org/10.1080/10095020.2019.1626135, 2019.

Aricò, C., Sinagra, M., Begnudelli, L., and Tucciarelli, T.: MAST2D diffusive model for flood prediction on domains with triangular Delaunay unstructured meshes, Adv. Water Resour., 34, 1427-1449, https://doi.org/10.1016/j.advwatres.2011.08.002, 2011.

Aricò, C., Filianoti, P., Sinagra, M., and Tucciarelli, T.: The FLO Diffusive 1D-2D Model for Simulation of River Flooding, Water, 8, 200, https://doi.org/10.3390/w8050200, 2016.
Arnone, E., Pumo, D., Viola, F., Noto, L. V., and La Loggia, G.: Rainfall statistics changes in Sicily, Hydrol. Earth Syst. Sci., 17, 2449-2458, https://doi.org/10.5194/hess-17-2449-2013, 2013.

Arnone, E., Pumo, D., Francipane, A., La Loggia, G., and Noto, L. V.: The role of urban growth, climate change, and their interplay in altering runoff extremes, Hydrol. Process., 32, 17551770, https://doi.org/10.1002/hyp.13141, 2018.

Bates, P.: Integrating remote sensing data with flood inundation models: how far have we got?, Hydrol. Process., 26, 2515-2521, 2012.

Bulti, D. T. and Abebe, B. G.: A review of flood modeling methods for urban pluvial flood application, Model Earth Syst. Environ., 6, 1293-1302, https://doi.org/10.1007/s40808-020-00803z, 2020.

Chow, V. T.: Open-channel hydraulics, McGraw-Hill, New York, 1959.

Cipolla, G., Francipane, A., and Noto, L. V.: Classification of Extreme Rainfall for a Mediterranean Region by Means of Atmospheric Circulation Patterns and Reanalysis Data, Water Resour. Manage., 34, 3219-3235, https://doi.org/10.1007/s11269020-02609-1, 2020.

Dayan, U., Nissen, K., and Ulbrich, U.: Review Article: Atmospheric conditions inducing extreme precipitation over the eastern and western Mediterranean, Nat. Hazards Earth Syst. Sci., 15, 2525-2544, https://doi.org/10.5194/nhess-15-2525-2015, 2015.

Di Baldassarre, G., Schumann, G., and Bates, P. D.: A technique for the calibration of hydraulic models using uncertain satellite observations of flood extent, J. Hydrol., 367, 276-282, https://doi.org/10.1016/j.jhydrol.2009.01.020, 2009.

Dottori, F. and Todini, E.: Testing a simple 2D hydraulic model in an urban flood experiment, Hydrol. Process., 27, 1301-1320, https://doi.org/10.1002/hyp.9370, 2013.

Drobinski, P., Da Silva, N., Panthou, G., Bastin, S., Muller, C., Ahrens, B., Borga, M., Conte, D., Fosser, G., Giorgi, F., Guttler, I., Kotroni, V., Li, L., Morin, E., Onol, B., Quintana-Segui, P., Romera, R., and Torma, C. Z.: Scaling precipitation extremes with temperature in the Mediterranean: past climate assessment and projection in anthropogenic scenarios, Clim. Dynam., 51, 1237-1257, https://doi.org/10.1007/s00382-016-3083-x, 2018.

Drusch, M., Del Bello, U., Carlier, S., Colin, O., Fernandez, V., Gascon, F., Hoersch, B., Isola, C., Laberinti, P., Martimort, P., Meygret, A., Spoto, F., Sy, O., Marchese, F., and Bargellini, P.: Sentinel-2: ESA's Optical High-Resolution Mission for GMES Operational Services, Remote Sens. Environ., 120, 25-36, https://doi.org/10.1016/j.rse.2011.11.026, 2012.

Easterling, D. R., Meehl, G. A., Parmesan, C., Changnon, S. A., Karl, T. R., and Mearns, L. O.: Climate extremes: Observations, modeling, and impacts, Science, 289, 2068-2074, https://doi.org/10.1126/science.289.5487.2068, 2000.

El Kadi Abderrezzak, K., Paquier, A., and Mignot, E.: Modelling flash flood propagation in urban areas using a twodimensional numerical model, Nat. Hazards, 50, 433-460, https://doi.org/10.1007/s11069-008-9300-0, 2009.

Filianoti, P., Gurnari, L., Zema, D. A., Bombino, G., Sinagra, M., and Tucciarelli, T.: An Evaluation Matrix to Compare Computer Hydrological Models for Flood Predictions, Hydrology, 7, 42, https://doi.org/10.3390/hydrology7030042, 2020.

Forestieri, A., Caracciolo, D., Arnone, E., and Noto, L. V.: Derivation of Rainfall Thresholds for Flash Flood Warning in a Sicilian 
Basin Using a Hydrological Model, Proced. Eng., 154, 818-825, https://doi.org/10.1016/j.proeng.2016.07.413, 2016.

Forestieri, A., Lo Conti, F., Blenkinsop, S., Cannarozzo, M., Fowler, H. J., and Noto, L. V.: Regional frequency analysis of extreme rainfall in Sicily (Italy), Int. J. Climatol., 38, e698-e716, https://doi.org/10.1002/joc.5400, 2018.

Gariano, S. L. and Guzzetti, F.: Landslides in a changing climate, Earth-Sci. Rev., 162, 227-252, https://doi.org/10.1016/j.earscirev.2016.08.011, 2016.

Grimaldi, S., Li, Y., Pauwels, V., and Walker, J.: Remote SensingDerived Water Extent and Level to Constrain Hydraulic Flood Forecasting Models: Opportunities and Challenges, Surv. Geophys., 37, 977-1034, 2016.

Hilbert, M.: Big Data for Development: A Review of Promises and Challenges, Dev. Policy Rev., 34, 135-174, https://doi.org/10.1111/dpr.12142, 2016.

Hoeppe, P.: Trends in weather related disasters - Consequences for insurers and society, Weather Clim. Extrem., 11, 70-79, https://doi.org/10.1016/j.wace.2015.10.002, 2016.

IPCC: Climate Change and Land: an IPCC special report on climate change, desertification, land degradation, sustainable land management, food security, and greenhouse gas fluxes in terrestrial ecosystems, edited by: Shukla, P. R., Skea, J., Calvo Buendia, E., Masson-Delmotte, V., Pörtner, H.-O., Roberts, D. C., Zhai, P., Slade, R., Connors, S., van Diemen, R., Ferrat, M., Haughey, E., Luz, S., Neogi, S., Pathak, M., Petzold, J., Portugal Pereira, J., Vyas, P., Huntley, E., Kissick, K., Belkacemi, M., and Malley, J., Geneva, Switzerland, 2019.

Jia, G., Shevliakova, E., Artaxo, P., Noblet-Ducoudré, N. D., Houghton, R., House, J., Kitajima, K., Lennard, C., Popp, A., Sirin, A., Sukumar, R., and Verchot, L.: Land-climate interactions, in: Climate Change and Land: an IPCC special report on climate change, desertification, land degradation, sustainable land management, food security, and greenhouse gas fluxes in terrestrial ecosystems, edited by: Shukla, J. S., Calvo Buendia, E., Masson-Delmotte, V., Pörtner, H.-O., Roberts, D. C., Zhai, P., Slade, R., Connors, S., van Diemen, R., Ferrat, M., Haughey, E., Luz, S., Neogi, S., Pathak, M., Petzold, J., Portugal Pereira, J., Vyas, P., Huntley, E., Kissick, K., Belkacemi, M., and Malley, J., Geneva, Switzerland, 2019.

La Loggia, G., Puleo, V., and Freni, G.: Floodability: A New Paradigm for Designing Urban Drainage and Achieving Sustainable Urban Growth, Water Resour. Manage., 34, 3411-3424, https://doi.org/10.1007/s11269-020-02620-6, 2020.

Lamb, R., Crossley, M., and Waller, S.: A fast twodimensional floodplain inundation model, Proc. Inst. Civ. Eng.-Water Manage., 162, 363-370, https://doi.org/10.1680/wama.2009.162.6.363, 2009.

Lhomme, J., Sayers, P., Gouldby, B., Samuels, P., and Wills, M.: Recent development and application of a rapid flood spreading method, Taylor \& Francis Group, London, ISBN 978-0-41548507-4, 15-24, 2009.

Liu, W., Chen, W. P., and Peng, C.: Assessing the effectiveness of green infrastructures on urban flooding reduction: A community scale study, Ecol. Model., 291, 6-14, https://doi.org/10.1016/j.ecolmodel.2014.07.012, 2014.

Liuzzo, L., Noto, L. V., Arnone, E., Caracciolo, D., and La Loggia, G.: Modifications in Water Resources Availability Under Climate Changes: A Case Study in a Sicilian Basin, Water Resour. Man- age., 29, 1117-1135, https://doi.org/10.1007/s11269-014-0864z, 2015.

Lu, D. S., Hetrick, S., Moran, E., and Li, G. Y.: Detection of urban expansion in an urban-rural landscape with multitemporal QuickBird images, J. Appl. Remote. Sens., 4, 041880, https://doi.org/10.1117/1.3501124, 2010.

Mason, D. C., Giustarini, L., Garcia-Pintado, J., and Cloke, H. L.: Detection of flooded urban areas in high resolution Synthetic Aperture Radar images using double scattering, Int. J. Appl. Earth Obs. Geoinform., 28, 150-159, https://doi.org/10.1016/j.jag.2013.12.002, 2014.

Mason, D. C., Dance, S. L., and Cloke, H. L.: Floodwater detection in urban areas using Sentinel-1 and WorldDEM data, J. Appl. Remote Sens., 15, 032003, https://doi.org/10.1117/1.Jrs.15.032003, 2021.

Mazzoleni, M., Alfonso, L., Chacon-Hurtado, J., and Solomatine, D.: Assimilating uncertain, dynamic and intermittent streamflow observations in hydrological models, Adv. Water Resour., 83, 323-339, https://doi.org/10.1016/j.advwatres.2015.07.004, 2015.

Mazzoleni, M., Cortes Arevalo, V. J., Wehn, U., Alfonso, L., Norbiato, D., Monego, M., Ferri, M., and Solomatine, D. P.: Exploring the influence of citizen involvement on the assimilation of crowdsourced observations: a modelling study based on the 2013 flood event in the Bacchiglione catchment (Italy), Hydrol. Earth Syst. Sci., 22, 391-416, https://doi.org/10.5194/hess-22391-2018, 2018.

Messeri, A., Morabito, M., Messeri, G., Brandani, G., Petralli, M., Natali, F., Grifoni, D., Crisci, A., Gensini, G., and Orlandini, S.: Weather-Related Flood and Landslide Damage: A Risk Index for Italian Regions, PLoS One, 10, e0144468, https://doi.org/10.1371/journal.pone.0144468, 2015.

Mignot, E., Paquier, A., and Haider, S.: Modeling floods in a dense urban area using 2D shallow water equations, J. Hydrol., 327 186-199, https://doi.org/10.1016/j.jhydrol.2005.11.026, 2006.

Moore, R. J.: The probability-distributed principle and runoff production at point and basin scales, Hydrolog. Sci. J., 30, 273-297, https://doi.org/10.1080/02626668509490989, 1985.

Noto, L. and la Loggia, G.: Derivation of a Distributed Unit Hydrograph Integrating GIS and Remote Sensing, J. Hydrol. Eng., 12, 639-650, https://doi.org/10.1061/(asce)10840699(2007)12:6(639), 2007.

Noto, L. V.: Exploiting the Topographic Information in a PDM-Based Conceptual Hydrological Model, J. Hydrol. Eng., 19, 1173-1185, https://doi.org/10.1061/(ASCE)HE.19435584.0000908, 2014.

Notti, D., Giordan, D., Calo, F., Pepe, A., Zucca, F., and Galve, J. P.: Potential and Limitations of Open Satellite Data for Flood Mapping, Remote Sens., 10, 1673, https://doi.org/10.3390/Rs10111673, 2018.

O'Callaghan, J. F. and Mark, D. M.: The extraction of drainage networks from digital elevation data, Comput. Vis. Graph. Image Proc., 28, 323-344, https://doi.org/10.1016/S0734189X(84)80011-0, 1984.

Oliveri, E.: Modellistica dei sistemi di drenaggio urbano: Analisi di situazioni ordinarie e straordinarie, $\mathrm{PhD}$ thesis, Biblioteche Nazionali di Roma e Firenze, Rome, Firenze, 1996.

Palla, A., Colli, M., Candela, A., Aronica, G. T., and Lanza, L. G.: Pluvial flooding in urban areas: the role of surface 
drainage efficiency, J. Flood Risk Manage., 11, S663-S676, https://doi.org/10.1111/jfr3.12246, 2018.

Pumo, D. and Noto, L. V.: Exploring the linkage between dew point temperature and precipitation extremes: A multi-time-scale analysis on a semi-arid Mediterranean region, Atmos. Res., 254, 105508, https://doi.org/10.1016/j.atmosres.2021.105508, 2021.

Pumo, D., Arnone, E., Francipane, A., Caracciolo, D., and Noto, L. V.: Potential implications of climate change and urbanization on watershed hydrology, J. Hydrol., 554, 80-99, https://doi.org/10.1016/j.jhydrol.2017.09.002, 2017.

Pumo, D., Carlino, G., Blenkinsop, S., Arnon, E., Fowler, H., and Noto, L. V.: Sensitivity of extreme rainfall to temperature in semi-arid Mediterranean regions, Atmos. Res., 225, 30-44, https://doi.org/10.1016/j.atmosres.2019.03.036, 2019.

Salvati, P., Petrucci, O., Rossi, M., Bianchi, C., Pasqua, A. A., and Guzzetti, F.: Gender, age and circumstances analysis of flood and landslide fatalities in Italy, Sci. Total Environ., 610-611, 867879, https://doi.org/10.1016/j.scitotenv.2017.08.064, 2018.

See, L.: A Review of Citizen Science and Crowdsourcing in Applications of Pluvial Flooding, Front Earth. Sci., 7, 44, https://doi.org/10.3389/Feart.2019.00044, 2019.

Sheffield, J. and Wood, E. F.: Projected changes in drought occurrence under future global warming from multi-model, multiscenario, IPCC AR4 simulations, Clim. Dynam., 31, 79-105, https://doi.org/10.1007/s00382-007-0340-z, 2008.

Sinagra, M., Nasello, C., Tucciarelli, T., Barbetta, S., Massari, C., and Moramarco, T.: A Self-Contained and Automated Method for Flood Hazard Maps Prediction in Urban Areas, Water, 12, 1266, https://doi.org/10.3390/w12051266, 2020.

Smith, L., Liang, Q., James, P., and Lin, W.: Assessing the utility of social media as a data source for flood risk management using a real-time modelling framework, J. Flood Risk Manage., 10, 370380, https://doi.org/10.1111/jfr3.12154, 2017.

Stone, K., Daanen, H. A. M., Jonkhoff, W., and Bosch, P.: Quantifying the sensitivity of our urban systems - impact functions for urban systems, Deltares, Delft, 2013.
Sušnik, J., Strehl, C., Postmes, L. A., Vamvakeridou-Lyroudia, L. S., Mälzer, H.-J., Savić, D. A., and Kapelan, Z.: Assessing Financial Loss due to Pluvial Flooding and the Efficacy of RiskReduction Measures in the Residential Property Sector, Water Resour. Manage., 29, 161-179, https://doi.org/10.1007/s11269014-0833-6, 2015.

Tramblay, Y. and Somot, S.: Future evolution of extreme precipitation in the Mediterranean, Climatic Change, 151, 289-302, https://doi.org/10.1007/s10584-018-2300-5, 2018.

Treppiedi, D., Cipolla, G., Francipane, A., and Noto, L. V.: Detecting precipitation trend using a multiscale approach based on quantile regression over a Mediterranean area, Int. J. Climatol., https://doi.org/10.1002/joc.7161, in press, 2021.

Trigila, A. and Iadanza, C.: Landslides and floods in Italy: hazard and risk indicators - Summary Report 2018, available at: https://www.isprambiente.gov.it/en/publications/reports/,landslidesand-floods-in-italy-hazard-and-risk-indicators-2013-summaryreport-2018 (last access: 23 August 2021), 2018.

Wallingford, H. R.: Rapid Flood Spreading Methodology (RFSM), HR Wallingford, 2006.

WECONS - Water Engineering Consulting: Servizi, available at: https://www.wecons.it/, last access: 23 August 2021.

Wolock, D. M. and McCabe Jr., G. J.: Comparison of Single and Multiple Flow Direction Algorithms for Computing Topographic Parameters in TOPMODEL, Water Resour. Res., 31, 1315-1324, https://doi.org/10.1029/95WR00471, 1995.

Yin, J. B., Gentine, P., Zhou, S., Sullivan, S. C., Wang, R., Zhang, Y., and Guo, S. L.: Large increase in global storm runoff extremes driven by climate and anthropogenic changes, Nat. Commun., 9, 1-10, https://doi.org/10.1038/S41467-018-06765-2, 2018.

Yu, D., Yin, J., and Liu, M.: Validating city-scale surface water flood modelling using crowd-sourced data, Environ. Res. Lett., 11, 124011, https://doi.org/10.1088/1748-9326/11/12/124011, 2016.

Zahmatkesh, Z., Burian, S. J., Karamouz, M., Tavakol-Davani, H., and Goharian, E.: Low-Impact Development Practices to Mitigate Climate Change Effects on Urban Stormwater Runoff: Case Study of New York City, J. Irrig. Drain. Eng., 141, $04014043-$ 1-04014043-13, https://doi.org/10.1061/(Asce)Ir.19434774.0000770, 2015. 